\title{
OPREDELITEV MEST IN MESTNIH OBČIN V REPUBLIKI SLOVENIJI
}

\author{
Igor Vrišer*
}

Izvleček

UDK $911 \cdot 375: 342.25$ (497.12)

Po predstavitvi dosedanjih opredelitev slovenskih mest so podana merila za dodelitev naslova mesto, ki slonijo na najpomembnejših socialnoekonomskih kazalcih.

Ključne besede: opredelitev mest, urbanizacija, Slovenija

DEFINITION OF CITIES AND CITY MUNICIPALITIES IN SLOVENIA

Abstract

UDC $911 \cdot 375: 342.25$ (497.12)

After the presentation of the hitherto definition of cities in Slovenia, the criteria are given for the allocation of the status of a city municipality, based on some most important socio-economic indicators.

Key words: Definition of cities, Urbanization, City rights, Slovenia

\section{PROBLEMI Z OPREDELJEVANJEM MEST IN MESTNIH OBČIN V SLOVENIJI ${ }^{1}$}

S sprejetjem "Zakona o lokalni samoupravi” (UL RS 72/93) se je v Sloveniji znova odprlo vprašanje opredeljevanja mest in mestnih občin. Navedeni zakon v 16. členu pravi, da "se na območju mesta zaradi enotnega prostorskega in urbanističnega urejanja, zadovoljevanja komunalnih potreb in planiranja razvoja ustanovi mestna občina, na katero lahko država prenese opravljanje določenih nalog iz svoje pristojnosti." Zakon dalje določa, da "mesto lahko dobi status mestne občine, če ima najmanj 10.000 prebivalcev in je geografsko, gospodarsko in kulturno središče svojega gravitacijskega območja". "Izjemoma lahko pridobi status mestne občine mesto iz zgodovinskih razlogov. O zahtevi mesta, da dobi status mestne občine, odloči državni zbor”.

S temi določbami se je po letu 1955, po uvedbi "komunalnega sistema", znova odprla možnost, da tudi slovenska mesta, vsaj večja med njimi, oziroma tista s posebnimi

\footnotetext{
* Dr., prof., Oddelek za geografijo, Filozofska fakulteta Univerze v Ljubljani, Aškerčeva 2, 61000 Ljubljana, Slovenija

${ }^{1}$ Poročilo je nastalo ob sprejemanju novega zakona o lokalni samoupravi kot prispevek za razpravo. Ker gre obenem za dokaj nov poskus ovrednotenja pomena slovenskih mest, smo sodili, da bo morda zanimivo tudi za širšo strokovno javnost., ki se ukvarja z mestnimi problemi.
} 
zgodovinskimi razlogi, dobijo poseben družbeni položaj in niso več izenačena $\mathrm{z}$ ostalimi naselji. Ob uvajanju "komunalnega sistema" se je zakonodajalec namreč odločil, da opusti mestom in trgom dodeljene tradicionalne posebne pravice in jih preprosto izenači z drugimi vaškimi, industrijskimi, turističnimi, rudarskimi itd. naselji. Po tej odločitvi so v upravnih razdelitvah Slovenije še nekaj let navajali območja mest, kot so jih določili 1. 1952 (Zakon o območjih okrajev in občin v Ljudski republiki Sloveniji, UL LRS 24/55, ter kasnejše novelacije tega zakona, UL SRS $37 / 60,3 / 61,39 / 62,39 / 62,8 / 63,35 / 64,10 / 65,42 / 66$ in 3/71), pozneje pa so to zaradi drugačne zasnove opustili. S tem je bil v takratni Sloveniji (in Jugoslaviji) dejansko odpravljen pojem "mesta" in "trga" oziroma se ga je uradno priznavalo le $v$ izjemnih primerih (npr. zaradi delitve Ljubljane na več občin je obstajal poseben mestni svet za ozemlje mesta Ljubljana). Po "komunalnem sistemu" so bile temeljne upravnopolitične enote zgolj občine, ki so na svojem ozemlju obsegale določeno število naselij, med njimi tudi mesta. Vse statistične in druge navedbe o mestih so bile glede na to ureditev pravzaprav neuradne in so nastale zgolj zaradi primerjav $\mathrm{s}$ tujino (seznam mest in mestnih naselij, ki sta ga objavljala Statistički godišnjak SFRJ in Statistični letopis SRS) oziroma iz nekaterih praktičnih razlogov (npr. zaradi "Zakona o nacionalizaciji stavb in stavbnih zemljišč", UL SRS 1/59). Drugi razlogi, da se je v upravi vendarle ohranjal pojem mesta, so bili komunalni, prostorskoplanerski in urbanistični (Zakon o uporabi zemljišč $v$ gradbene namene UL SRS 13/56; Zakon o urbanističnih projektih, UL SRS 22/58; Zakon o urbanističnem planiranju, UL SRS 16/67) (3). Tako so mestom vendarle priznavali, da niso zgolj teritorialni pojem, ampak so dejansko obsežnejši in dokaj zapleteni družbeni in prostorski organizmi. Prav to je skozi vsa zgodovinska obdobja terjalo od upravljalcev posebno obravnavo mest in $\mathrm{s}$ tem $\mathrm{v}$ zvezi njihov drugačni pravni položaj ter, ne nazadnje, tudi opredelitev njihovega ozemlja.

Upravna obnovitev pojma mesto, ki izhaja iz zakona o lokalni samoupravi, je postavila Državni zbor Republike Slovenije in druge upravne organe pred nalogo, da odločijo o več različnih problemih in dilemah:

1. Katerim mestom priznati status mestne občine na podlagi preseženega števila 10.000 prebivalcev in večjega geografskega, gospodarskega in kulturnega pomena.

2. Kako določiti število prebivalcev $\mathrm{v}$ mestih, ko mesta $v$ Sloveniji niso bila $\mathrm{z}$ enotnimi merili teritorialno opredeljena oziroma se je njihovo pojmovanje $v$ statistični službi mešalo s takoimenovanimi "mestnimi naselji". Razen tega sta se "Zakon o postopku za ustanovitev, združitev oziroma spremembo območja občine ter o območjih občine" (UL SRS 28/80, 9/82, 27/84, 38/89 in UL RS 30/90) in "Zakon o imenovanju in evidentiranju naselij, ulic in stavb" (UL SRS 5/80) različno uporabljala, kar je pripeljalo do znatnih razlik $v$ velikosti in ozemeljskem obsegu mest in mestnih naselij. 
3. Razmišljanja o podeljevanju naslova "mestna občina" zapletajo nekateri primeri somestij, ki jih je v Sloveniji kar nekaj (Piran-Portorož-Lucija, Ravne-Prevalje, Radovljica-Lesce, Velenje-Šoštanj) in kjer bodo bržkone urbanistični interesi v navzkrižju z ljudskimi pogledi in odločitvami ne glede na funkcionalno povezanost in medsebojno prostorsko delitev dela med temi naselji.

4. Tudi možna uporaba pravno-historičnega kriterija pri dodelitvi mestnega naslova posameznim mestom odpira celo vrsto vprašanj: ne le da so pojmi "mesto" in "trg" v minulih štiridesetih letih izgubili nekdanji pomen, ampak je naselbinski razvoj prinesel celo vrsto novih tipov naselij, ki nimajo več veliko skupnega s historičnimi mesti, kaj šele z nekdanjimi trgi. Razen tega kaže upoštevati, da že pod Avstroogrsko in $v$ Kraljevini Jugoslaviji podeljevanje mestnih in tržnih pravic ni bilo zgledno urejeno in je vodilo k nekaterim neupravičenim razlikam. Zato je moč pričakovati tudi glede tega zakonskega določila vrsto razprav in pomislekov.

\section{DOSEDANJE OPREDELITVE MEST}

Ob vsem tem kaže opozoriti, da opredeljevanje mest tudi drugod po svetu ni najbolj smiselno in smotrno urejeno in da obstajajo med državami znatne razlike. V Evropi so na sploh prevladovali pravno-historični kriteriji, po katerih je dobilo naselje mestni naslov na podlagi vladarjeve, skupščinske ali vladne odločbe. Pretežna večina mest je te naslove prejela že $\mathrm{v}$ srednjem ali novem veku, manjše število mest, ki so zrasla v 19. ali 20. stoletju, pa je te pravice dobilo kasneje po posebni proceduri ali z nakupom naslova. Mestni status se je praviloma priznaval tistemu ozemlju, na katerem se je razprostirala mestna občina, vendar so mnoga mesta svoje ozemlje po dolgotrajnih upravnih postopkih razširila še na nekatere okoliške občine in jih vključila v mesto. Ta praksa se je uporabljala tudi na ozemlju sedanje Republike Slovenije, ko je še bila del Avstro-Ogrske oziroma Kraljevine Jugoslavije.

Razvoj naselij in naselbinskega omrežja pa je marsikje to prvotno zgradbo mest (in trgov) prehitel in vnesel $v$ mestno omrežje celo vrsto anahronizmov, kot so bila npr. stara "pritlikava" historična mesteca (pri nas Kostanjevica, Lož, Vipavski Križ ali Višnja Gora), ki niso imela niti mestnega pomena niti značaja. Do navzkrižij je prihajalo tudi pri inkorporacijah sosednjih občin $v$ mestne, čemur so se prizadeti večidel krčevito upirali, čeprav je razvoj mest terjal takšne upravne spremembe (npr. inkorporiranje občin Šiška, Vič, in Moste v Mestno občino ljubljansko I. 1936). Do posebnih težav je prišlo tudi tam, kjer so se mesta zaradi intenzivne urbanizacije združevala $v$ enotno urbano maso, ki so jo delile le še preživete upravne meje. Po drugi svetovni vojni se je takšno zraščanje $v$ somestja ali konurbacije pojavilo tudi $v$ Sloveniji. Vse to je povzročalo, da so marsikje zelo kritično obravnavali historične opredelitve in iskali pota za posodobitev, vendar so se prizadeta naselja in mesta tovrstnim spremembam večinoma upirala. 
V deželah, ki niso imele tovrstne historične dediščine, so mesta večidel opredeljevali z normativnimi kazalci, najpogosteje s številom prebivalcev. To stališče je prevladalo že na mednarodnem statističnem kongresu v Parizu I. 1887, ko so se odločili za spodnjo velikostno mero mest pri 2000 prebivalcih, kar je ustrezalo takratni urbanizacijski stopnji. Po drugi svetovni vojni so eksperti Združenih narodov priporočili za mesta spodnjo velikostno mejo 10.000 prebivalcev. Ta številka bi $v$ glavnem ustrezala napredku urbanizacije širom sveta, ki se je po drugi svetovni vojni vsepovsod izredno povečala.

V Jugoslaviji so po drugi svetovni vojni sprva razmišljali o uporabi meje 2000 prebivalcev, vendar se je pokazalo, da je to število za srbska in zlasti za vojvodinska in slavonska mesta odločno prenizko, za slovenska mesta pa marsikdaj previsoko. Zaradi velikih razlik med republikami in regijami je statistik Miloš Macura skušal izdelati kombinirani kriterij za opredeljevanje mest. Po njegovi zamisli, ki jo je potem zvezni zavod za statistiko uporabljal pri vseh popisih prebivalstva (1953-1981), so določili mestni značaj s kombiniranjem dveh kriterijev: števila prebivalcev $v$ naselju in deleža neagrarnega prebivalstva. $\mathrm{S}$ tem se je skušalo izločiti velike panonske in balkanske vasi, ki so pogosto štele preko 2000 prebivalcev, a so po gospodarski ali funkcijski plati bile izrazito agrarne. $\mathrm{S}$ povezovanjem teh dveh kriterijev je prišla do večje veljave urbanost malih slovenskih, dalmatinskih in bosanskih mestec. V vsakokratnih publiciranih popisih prebivalstva (vendar le $v$ določenih knjigah) so bila tovrstna naselja označena s črko G (= gradska), vmesna s črko M (= mešana) in vsa ostala s črko S (=selo) (5). Ta statistična opredelitev ni imela širšega pomena, saj je niso uporabljali $\mathrm{v}$ upravne namene.

Slovenske oblasti tem statističnim pobudam niso sledile. V Kraljevini Jugoslaviji so ohranile staro opredelitev mest, prevzeto še iz Avstroogrske. Mestne pravice so dodelile le nekaterim novim krajem. Tako je bilo mestno omrežje na ozemlju Republike Slovenije sestavljeno iz:

1. starih fevdalnih mest, ki so prejela mestni naslov $\mathrm{v}$ srednjem ali novem veku; to so bila mesta: Brežice, Celje, Črnomelj, Idrija, Izola, Kamnik, Kočevje, Koper, Kostanjevica, Kranj, Krško, Ljubljana, Lož, Maribor, Metlika, Novo mesto, Ormož, Piran, Ptuj, Radovljica, Slovenj Gradec, Slovenska Bistrica, Škofja Loka, Vipavski Križ in Višnja gora;

2. mest, ki so dobila mestne pravice v 19. ali 20. stoletju: Gornji Grad, Jesenice, Laško, Ljutomer, Postojna, Šoštanj, Tržič in v takratnem italijanskem delu Slovenskega Primorja Ilirska Bistrica.

Skupaj je bilo torej 25 starih mest in osem kasneje proglašenih ali v celoti 33 mest. 
Po drugi svetovni vojni so oblasti v prvem desetletju izvedle nekaj obsežnih sprememb. Tako so I. 1952 na podlagi "Zakona o razdelitvi Ljudske republike Slovenije na mesta, okraje in občine" (UL LRS 11/52) ter s kasnejšimi dopolnitvami in popravki (UL LRS 19/52, 31/52, 43/54) dodelile naslov mesta in poseben pravni položaj Ljubljani, Mariboru in Celju. Naslov "mestne občine s posebnimi pravicami" so dobile občine: Bled, Idrija, Jesenice, Kamnik, Kranj, Murska Sobota, Nova Gorica, Novo mesto, Postojna, Ptuj, Škofja Loka, Trbovlje in Tržič. Status "mestne občine" pa je dobilo naslednjih 31 občin: Ajdovščina, Bovec, Brežice, Ćrnomelj, Gornja Radgona, Hrastnik, Ilirska Bistrica, Kočevje, Kostanjevica, Laško, Lendava, Litija, Ljutomer, Metlika, Ormož, Radeče, Radovljica, Ravne na Koroškem, Sevnica, Sežana, Slovenska Bistrica, Slovenj Gradec, Slovenske Konjice, Šoštanj, Tolmin, Velenje, Videm-Krško, Višnja Gora, Vrhnika, Zagorje ob Savi. K temu seznamu mest so kasneje dodali še Žalec. Število mest je na ta način naraslo na 51. Delitev mest na te tri kategorije: mesta, mestne občine v sestavi okraja, ki imajo posebne pravice, ter druge mestne občine, je dejansko prinesel Zakon o ljudskih odborih mest in mestnih občin (Ul. LRS 19/52). S temi zakoni je bil mestom podeljen status pravne osebe.

Z "Zakonom o območjih okrajev in občin v SR Sloveniji" (UL SRS, 35/64) ter njegovimi kasnejšimi popravki in novelacijami, kot tudi z "Zakonom o imenovanju in evidentiranju naselij, ulic in stavb" (UL SRS 5/80) ter "Zakonom o postopku za ustanovitev, združitev oziroma spremembo območja občin ter o območju občin" (UL SRS $28 / 80$ ), so oblasti ozemeljsko opredelitev mest še ohranile, toda po pravnem položaju so odpravile razlikovanje med mesti, mesti s posebnimi pravicami in mestnimi občinami oziroma so postopoma mesta izenačile $z$ drugimi naselji. Spiska mest iz l. 1952 sicer niso nikoli preklicale, vendar pa mu tudi niso pripisovale nobenega posebnega pomena.

Takšne razmere so spravljale v zadrego vse tiste upravne službe, ki so se ukvarjale z mesti, saj se je vedno znova zastavljalo vprašanje, katere kraje šteti za mesta. Problem je bil toliko bolj aktualen, ker že navedeni spisek iz l. 1952 ni zajel vseh naselij, ki so imela vsaj deloma mestni značaj (npr. Dravograd, Ruše, Mežica), priznal pa je mestni naslov nekaterim krajem, ki so bila v preteklosti zgolj trgi (npr. Bovec, Radeče) ali pa tudi to ne (npr. Sežana, Bled, Hrastnik). Spisek je postal v teku let močno zastarel, saj so $v$ tem času mnoga naselja znatno povečala število svojega prebivalstva in pridobila v določeni meri mestni značaj in pomen (npr. Mengeš, Rogaška Slatina, Zreče, Portorož, Železniki itd.). Ob tem seznamu je ostalo tudi docela odprto vprašanje ali v mesta vključiti bližnja močno urbanizirana naselja, ki so se strnjeno povezala $\mathrm{z}$ mestom, ali ostati pri njihovem prvotnem teritorialnem obsegu.

Iz teh razlogov so se na statističnem zavodu Republike Slovenije že v šestdesetih letih odločili, da sestavijo poseben spisek "mestnih naselij", ki bi zajel poleg pravih mest še druge močno urbanizirane naselbine kot tudi bližnja urbanizirana naselja. To je bilo 
potrebno, ker po eni strani citirana metoda M. Macure, ki jo je uporabljal zvezni statistični zavod, s spiskom 68 slovenskih mest ni povsem ustrezala dejanskim razmeram in potrebam, po drugi strani pa je vendarle bilo treba izločiti tudi različna manjša središča, sedeže občin, turistične in industrijske kraje, ki so izstopali glede na svojo urbaniziranost in vlogo. Zaradi drugačnega metodološkega pristopa so spisek teh mestnih naselij na republiškem statističnem zavodu občasno prenovili, dodali nove kraje in izpustili tiste, ki so se med tem vključili v mesta. Spisek so, kot sami poročajo, sestavili ob pomoči geodetskih, urbanističnih in geografskih strokovnjakov in seveda statistikov. Za primerjavo navedimo, da je ta spisek štel ob popisu prebivalstva 1. 1981243 in 1.1991166 mestnih naselij, to je pravih mest, malih mest, razvitejših turističnih in industrijskih naselij, lokalnih središč in bližnjih urbaniziranih naselij.

Spisek mestnih naselij je doživljal spremembe iz še enega razloga: zakonodaja o naseljih je namreč dopuščala ozemeljske spremembe ("Zakon o imenovanju in evidentiranju naselij, ulic in stavb", UL SRS $5 / 80$; ter "Zakon o postopku za ustanovitev, združitev oziroma spremembo območja občin ter o območju občin"; UL SRS 28/80) in sicer ali osnovanje novih naselij, ukinitev ali združitev obstoječih, delno priključitev naselij k mestu ali k drugemu večjemu naselju itd. Nekatera mesta so se tega ukrepa poslužila in zaokrožila svoj mestni teritorij, druga zopet so se zadovoljila s tem, da so ob mestu navedla tudi bližnja urbanizirana naselja, ki so predstavljala nekakšna predmestja ali mestne satelite. Iz teh razlogov so danes med slovenskimi mesti znatne razlike glede števila prebivalstva in ozemlja. Razen tega je navedena komisija pri zavodu za statistiko spreminjala kriterije pri opredeljevanju mestnih naselij ter ne redko nekatera naselja vnesla $v$ spisek, drugič zopet pa ta ista naselja izločila (značilen primer so Radeče, ki so bile 1. 1952 uvrščene med mesta, a so jih npr. v seznamu za l. 1981 in 1991 izpustili). V spisku manjkajo tudi nekateri drugi kraji, ki bi morda zaslužili uvrstitev, npr. Ankaran, Beltinci, Črna na Koroškem, Lovrenc na Pohorju, Šenčur pri Kranju, Trzin, Vrtojba, itd.). Žal komisija ni obrazložila, na podlagi katerih kriterijev je izbirala mestna naselja. Vse to je povzročalo, da se je zmešnjava pri opredeljevanju mest $v$ Republiki Sloveniji nadaljevala in da nobeden od navedenih načinov ni prinesel zadovoljive rešitve.

Iz vsega tega je razvidno, da sta se doslej $v$ praksi uporabljala $v$ glavnem dva kriterija: zgodovinsko-pravna opredelitev in številčnost mestnega prebivalstva. Zaradi velikih vsebinskih razlik med obema kriterijema je očitno, da obeh pogojev ni mogoče hkrati uporabljati, saj se vsebinsko razhajata ali celo izključujeta. To velja tudi za določila o podeljevanju naslova "mestne občine", ki so navedena v 16. členu zakona o lokalni samoupravi. Prav zato je pričakovati, da bo to določilo izzvalo zelo obsežno razpravo in znatna razhajanja. Po našem mnenju bi bilo glede na to smiselno, ko bi zakonodajalec razlikoval med pojmom "mestna občina" na eni strani in pojmom "mesto" na drugi. Prvi naziv bi prizadeti občini dajal določene posebne pravice in dolžnosti, kot je to navedeno $\vee$ zakonu o lokalni samoupravi, drugi pa bi po upravni 
poti obnovil naziv, ki si ga je mesto $\mathrm{v}$ preteklosti pridobilo ali pa bi mu glede na določeno število prebivalcev, značaj in pomen pripadalo. Seveda bi bilo treba seznam zgodovinskih mest razširiti še z nekaterimi drugimi, pozneje nastalimi mesti. Pri podeljevanju naslova "mesto" bi, podobno kot pri dodelitvi naslova mestna občina, morala zainteresirana mesta izpolniti določene pogoje, ki bi izhajali iz pomenske opredelitve pojma mesto.

Iz tako zastavljenih razmišljanj sledi, da bi morala biti obravnava meril za opredelitev mest in mestnih občin dvojna; obsegala bi: 1 . določitev mest, ki izpolnjujejo pogoje za proglasitev mestne občine, in 2. opredelili bi naselja, ki bi izpolnjevala pogoje za dodelitev naslova "mesto".

Pri praktični izvedbi pa bi morali oba poskusa vrednotenja izvesti v treh variantah; pri vseh mestih bi bilo treba določiti ali bomo upoštevali pri opredeljevanju:

a) zgolj imenovana naselja, ali pa bomo

b) k obravnavanemu naselju prišteli še bližnja okoliška "mestna naselja", ki so po svojem urbanem značaju $v$ tolikšni meri zraščena $z$ mestom, da bi jih kazalo obravnavati kot del mesta, kot so to smiselno že storili na republiškem zavodu za statistiko, ko so sestavili seznam "mestnih naselij" (Cerovac, 1974), ali pa bi bilo treba

c) zaradi velikih razlik med mesti, ko so $\mathrm{k}$ nekaterim mestom bližnja naselja že priključili (npr. Ljubljana, Novo mesto), k drugim pa ne (npr. Maribor, Celje, Kranj), obravnavati vsa mesta in njim bližnja naselja $\mathrm{z}$ enakimi merili in na podlagi teh izsledkov pripraviti nov seznam mest in mestnih naselij, ki bi jih kazalo slej ko prej upravno priključiti k mestu. S tem bi dobili perspektivo oblikovanja novih mestnih občin oziroma mest in bi poenotili že opravljena vrednotenja.

\section{MERILA ZA OPREDELITEV MEST, KI IZPOLNJUJEJO POGOJE ZA PROGLASITEV MESTNE OBČINE}

1. Osnovno določilo, ki izhaja že iz zakona, je zahteva, da naj ima mesto več kot 10.000 prebivalcev. To merilo lahko dopolnimo $\mathrm{v}$ smislu točk b) in c), to je, da mestu priključimo bližnja in z njim tesno zraščena naselja ter tako povečamo mestno prebivalstvo.

2. Bolj zapletena naloga je, kako meriti geografski, gospodarski in kulturni pomen mesta. Glede na razpoložljivo statistično gradivo smo uporabili naslednje kazalce: 
- indekse rasti mestnega prebivalstva, ki so v mestih praviloma visoki in ki kažejo na težnjo po družbenem vzponu (merili smo jih za razdobji 1991/1953 in 1991/1981);

- število zaposlenih (delovnih mest), ki naj bi pokazalo gospodarski pomen mesta (po podatkih popisa prebivalstva 1. 1991);

- razmerje med prebivalci in zaposlenimi, ki bi moralo biti v mestih praviloma dokaj izenačeno glede na osredotočenost delovnih mest; visok koeficient bi pomenil, da je naselje bolj stanovanjska kolonija, kot pa pravo mesto;

- delež kmečkega prebivalstva, ki bi potrjeval pretežno urbani značaj naselja (po popisu prebivalstva 1. 1991);

- visoka gostota prebivalstva (število prebivalcev na ha), ki bi morala biti v mestih znatno večja kot na podeželju (površina naselij po podatkih geodetske uprave RS);

- gospodarski pomen mesta glede na ustvarjeni družbeni proizvod (po podatkih republiškega zavoda za statistiko za I. 1990).

Tem kazalcem smo dodali še tri merila, ki so rezultat dosedanjih geografskih proučevanj naših mest in ki kažejo geografski, gospodarski in kulturni pomen posameznega mesta; to so:

- hierarhična stopnja, ki jo je imelo mesto v omrežju centralnih naselij in ki je kazalo pomen mesta v sistemu centralnih naselij (Vrišer, 1974);

- število pomembnejših funkcij, ki jih je imelo mesto na ožji (urbani) in na širši (regionalni) ravni; ugotovili smo jih bodisi na podlagi visokega deleža posameznih dejavnosti $v$ strukturi delovnih mest $v$ mestu oziroma nadpovprečnega deleža posameznih mestnih dejavnosti glede na dejavnostno strukturo vseh slovenskih mest (Vrišer, 1990);

- število prebivalcev na mestnem vplivnem območju na vicinalni, mikroregionalni in mezoregionalni ravni, kar bi odražalo vlogo mesta $v$ centralnonaselbinskem omrežju, njegovo opremljenost s storitvenimi dejavnostmi ter navezanost okoličanov na mestno središče; podatke smo ocenili na podlagi odgovorov posameznih krajevnih skupnosti, v katerih centralnih naseljih oziroma mestih njihovi prebivalci kupujejo ali uporabljajo različne storitve in so veljali za sredo osemdesetih let (Vrišer, 1988).

Pri presoji, katera mesta imajo ustrezne pogoje za proglasitev mestne občine, smo vzeli v obzir vsa mesta, ki so imela več kot 10.000 prebivalcev. Zanje smo izračunali navedene indikatorje, vendar brez upoštevanja Ljubljane in Maribora, saj bi vključitev teh dveh mest zelo dvignila povprečja. Iz dobljenih povprečnih in minimalnih vrednosti kazalcev in na tej osnovi sprejetih mejnih vrednosti je bilo mogoče sklepati, 
katera mesta znatneje zaostajajo oziroma ne presegajo postavljenih mejnih vrednosti. Upoštevali smo naslednja mesta: Celje, Domžale, Izola, Jesenice, Koper, Kranj, Ljubljana, Maribor, Murska Sobota, Nova Gorica, Novo mesto, Ptuj, Škofja Loka, Trbovlje in Velenje. Njim smo kasneje dodali še Kamnik, Kočevje in Zagorje, ki so se uvrstila na podlagi "priključitve" urbaniziranih naselij.

Primerjavo smo izvedli $v$ treh variantah: A) ob upoštevanju zgolj imenovanega naselja, B) z vključitvijo bližnjih "mestnih naselij", kot jih je opredelil zavod za statistiko, in C) z vključitvijo tistih bližnjih naselij, ki jih je določil avtor z novo enotno metodo.

Tabela 1: Merila za opredelitev mestnih občin

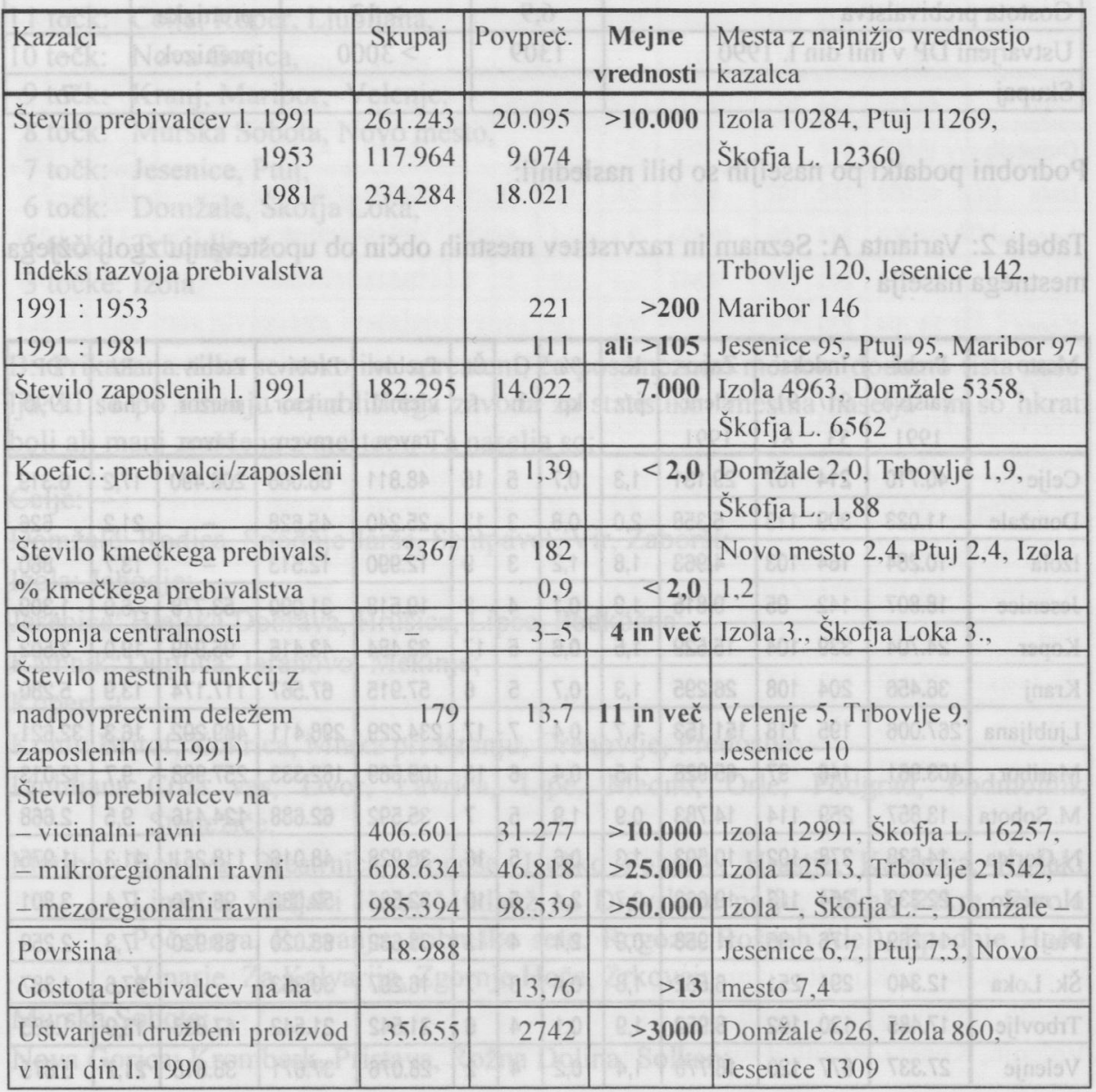


Za boljše razumevanje navajamo primer računanja točk za Jesenice:

\begin{tabular}{|l|c|c|c|c|}
\hline Kazalec & stanje & normativ & ustreznost & točke \\
\hline Indeks razvoja prebivalstva & 142 ali 95 & $>200$ ali $>105$ & prenizek & - \\
\hline Število zaposlenih & 9815 & $>7000$ & presega & 1 \\
\hline Koeficient: bivajoči / zaposleni & 1,9 & $<2,0$ & ustreza & 1 \\
\hline$\%$ kmečkega prebivalstva & 0,1 & $<2,0$ & ustreza & 1 \\
\hline Stopnja centralnosti & 4 & 4 in več & ustreza & 1 \\
\hline Število mestnih funkcij & 8 & 11 in več & prenizko & - \\
\hline Št. prebivalcev na vplivnem območju na & & & & \\
- vicinalni ravni & 19518 & $>10000$ & presega & 1 \\
- mikroregionalni ravni & 31090 & $>25000$ & presega & 1 \\
- mezoregionalni ravni & 53778 & $>50000$ & presega & 1 \\
\hline Gostota prebivalstva & 6,9 & $>13$ & prenizka & - \\
\hline Ustvarjeni DP v mil din l. 1990 & 1309 & $>3000$ & prenizek & - \\
\hline Skupaj & & & & 7 \\
\hline
\end{tabular}

Podrobni podatki po naseljih so bili naslednji:

Tabela 2: Varianta A: Seznam in razvrstitev mestnih občin ob upoštevanju zgolj ožjega mestnega naselja

\begin{tabular}{|c|c|c|c|c|c|c|c|c|c|c|c|c|}
\hline Mesto & $\begin{array}{c}\text { Prebi- } \\
\text { valstvo } \\
1991 \\
\end{array}$ & $\begin{array}{ll}\text { Indeksi } \\
91 / & 91 / \\
53 & 81 \\
\end{array}$ & $\begin{array}{c}\text { Zapo- } \\
\text { sleni } \\
1991 \\
\end{array}$ & $\begin{array}{l}\mathrm{K} . \\
\mathrm{p} / \mathrm{z}\end{array}$ & $\begin{array}{l}\% \\
k p\end{array}$ & $\begin{array}{l}\mathrm{C} \\
\mathrm{n}\end{array}$ & $\begin{array}{l}\text { Št } \\
\text { f. }\end{array}$ & $\begin{array}{c}\text { Prebiv. } \\
\text { vicinal. } \\
\text { raven }\end{array}$ & $\begin{array}{c}\text { Prebiv. } \\
\text { mikror. } \\
\text { raven }\end{array}$ & $\begin{array}{c}\text { Prebiv. } \\
\text { mezor. } \\
\text { raven }\end{array}$ & $\begin{array}{l}\mathrm{P} / \\
\text { ha }\end{array}$ & $\begin{array}{c}\text { DP } \\
1990\end{array}$ \\
\hline Celje & 40.710 & $\begin{array}{ll}214 & 107 \\
\end{array}$ & 29.131 & 1,3 & 0,7 & 5 & 15 & 48.811 & 88.068 & 208.490 & 17,2 & 6.319 \\
\hline Domžale & 11.023 & $309 \quad 113$ & 5.358 & 2,0 & 0,8 & 3 & 13 & 25.240 & 45.628 & - & 21,2 & 626 \\
\hline Izola & 10.284 & $164 \quad 103$ & 4.963 & 1,8 & 1,2 & 3 & 9 & 12.990 & 12.513 & - & 13,7 & 860 \\
\hline Jesenice & 18.807 & $142 \quad 95$ & 9.815 & 1,9 & 0,1 & 4 & 8 & 19.518 & 31.090 & 53.778 & 6,9 & 1.309 \\
\hline Koper & 24.704 & $339 \quad 104$ & 15.529 & 1,5 & 0,6 & 5 & 17 & 32.484 & 43.415 & 95.949 & 19,0 & 3.503 \\
\hline Kranj & 36.456 & $204 \quad 108$ & 26.295 & 1,3 & 0,7 & 5 & 6 & 57.915 & 67.567 & 117.174 & 13,9 & 5.280 \\
\hline Ljubljana & 267.006 & $195 \quad 118$ & 151.153 & 1,7 & 0,4 & 7 & 17 & 234.229 & 298.411 & 489.292 & 16,3 & 32.621 \\
\hline Maribor & 103.961 & $\begin{array}{ll}146 \quad 97 \\
\end{array}$ & 65.928 & 1,5 & 0,4 & 6 & 13 & 109.569 & 182.333 & 257.988 & 9,7 & 12.013 \\
\hline M. Sobota & 13.857 & $259 \quad 114$ & 14.783 & 0,9 & 1,9 & 5 & 7 & 35.592 & 62.688 & 124.416 & 9,5 & 2.668 \\
\hline N.Gorica & 14.638 & $\begin{array}{ll}378 & 102 \\
\end{array}$ & 10.503 & 1,3 & 0,6 & 5 & 16 & 36.928 & 48.016 & 118.261 & 41,3 & 1.975 \\
\hline N. mesto & 22.333 & $264 \quad 113$ & 19.668 & 0,7 & 2,4 & 5 & 10 & 32.585 & 52.063 & 96.750 & 7,4 & 3.801 \\
\hline Ptuj & 11.269 & $176 \quad 95$ & 11.958 & 0,9 & 2,4 & 4 & 13 & 38.632 & 68.020 & 83.920 & 7,3 & 2.259 \\
\hline Šk. Loka & 12.340 & 291251 & 6.562 & 1,8 & 0,4 & 3 & 7 & 16.297 & 30.353 & - & 27,6 & 1.387 \\
\hline Trbovlje & 17.485 & $120 \quad 102$ & 8.952 & 1,9 & 0,1 & 4 & 6 & 21.542 & 21.542 & 47.838 & 13,9 & 1.685 \\
\hline Velenje & 27.337 & $\begin{array}{ll}677 & 120\end{array}$ & 18.778 & 1,4 & 0,2 & 4 & 2 & 28.076 & 37.671 & 38.818 & 21,7 & 3.875 \\
\hline
\end{tabular}


$\mathrm{K} \cdot \mathrm{p} / \mathrm{z}=$ koeficient med prebivalci in zaposlenimi

$\% \mathrm{kp}=$ odstotek kmečkega prebivalstva

$\mathrm{C} \mathrm{n} \quad=$ stopnja $\mathrm{v}$ hierarhiji centralnih naselij

Št f. = skupno število "urbanih" in "regionalnih" funkcij, ki glede na odstotek zaposlenih presegajo povprečje

Prebiv. vicinal., mikror., mezor. raven $=$ Število prebivalcev na vicinalni, mikroregionalni in mezoregionalni ravni na vplivnem območju mesta

$\mathrm{P} / \mathrm{ha}=$ gostota prebivalstva, število prebivalcev na hektar

DP = na mestnem ozemlju ustvarjeni družbeni proizvod v mil. din 1. 1990 in sicer na ozemlju mesta in v "mestnih naseljih". Slednji podatek smo uporabili tudi pri varianti $\mathrm{C}$.

Rezultat točkovanja je bil naslednji:

11 točk: Celje, Koper, Ljubljana,

10 točk: Nova Gorica,

9 točk: Kranj, Maribor, Velenje,

8 točk: Murska Sobota, Novo mesto,

7 točk: Jesenice, Ptuj,

6 točk: Domžale, Škofja Loka,

5 točk: Trbovlje

3 točke: Izola

B: Prikazana slika se nekoliko spremeni, če posameznim mestom dodamo tista naselja, ki so po mnenju republiškega zavoda za statistiko "mestna naselja" in so hkrati bolj ali manj zraščena $\mathrm{z}$ mestom. Ta naselja so:

Celje: -

Domžale: Rodica, Spodnje Jarše, Šentpavel, Vir, Zaboršt;

Izola: Jagodje;

Jesenice: Blejska Dobrava, Hrušica, Lipce, Podkočna;

Kamnik: Duplica, Jeranovo, Mekinje;

Koper: -

Kranj: Britof, Kokrica, Mlaka pri Kranju, Orehovlje, Predoslje;

Ljubljana: Črna vas, Dvor, Lavrica, Lipe, Medno, Orle, Podgrad, Podmolnik, Stanežiče;

Maribor: Bohova, Brestrnica, Dogoše, Hočko Pohorje, Hrastje, Kamnica, Košaki, Limbuš, Meljski Hrib, Miklavž na Dravskem polju, Pekel, Pekre, Pivola, Počehova, Razvanje, Ribniško selo, Rogoza, Rošpoh (del), Spodnje Hoče, Vinarje, Za Kalvarijo, Zgornje Hoče, Zrkovci;

Murska Sobota: -

Nova Gorica: Kromberk, Pristava, Rožna Dolina, Solkan; 
Novo mesto: -

Ptuj: Budina, Krčevina, Nova vas pri Ptuju, Orešje, Rabeljčja vas, Rogoznica, Spodnja Hajdina, Štuki, Vičava;

Škofja Loka: Grenc, Podpulferca, Puštal, Stara Loka, Suha, Sveti Duh, Trata, Vincarje, Virmaše;

Trbovlje: -

Velenje:

Tabela 3: Varianta B: Seznam in razvrstitev mestnih občin ob priključitvi bližnjih "mestnih naselij" k mestom (po opredelitvi republiškega zavoda za statistiko)

\begin{tabular}{|c|c|c|c|c|c|c|c|c|c|c|c|c|}
\hline & $\begin{array}{c}\text { Prebi- } \\
\text { valstvo } \\
1991 \\
\end{array}$ & $\begin{array}{c}\text { Indeksi } \\
91 / \quad 91 / \\
53 \quad 81 \\
\end{array}$ & $\begin{array}{l}\text { Lapo- } \\
\text { sleni } \\
1991 \\
\end{array}$ & $\begin{array}{l}K . \\
P / z\end{array}$ & $\begin{array}{l}\% \\
k p\end{array}$ & $\begin{array}{l}\mathrm{C} \\
\mathrm{n}\end{array}$ & $\begin{array}{l}\text { St } \\
\text { f. }\end{array}$ & $\begin{array}{c}\text { Prebiv. } \\
\text { vicinal. } \\
\text { raven }\end{array}$ & $\begin{array}{c}\text { Prebiv. } \\
\text { mikror. } \\
\text { raven }\end{array}$ & $\begin{array}{c}\text { Prebiv. } \\
\text { mezor. } \\
\text { raven }\end{array}$ & $\begin{array}{l}\text { P/ } \\
\text { ha }\end{array}$ & $\begin{array}{c}\text { DP } \\
1990\end{array}$ \\
\hline & & $\begin{array}{ll}214 & 107 \\
\end{array}$ & & 1,3 & 0,7 & 5 & 15 & & .068 & 08.490 & 17,2 & 631 \\
\hline & & $378 \quad 141$ & & 2,1 & 0,7 & 3 & 13 & & & 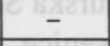 & 15,8 & 1.296 \\
\hline & & $152 \quad 102$ & 945 & 2,0 & 1,2 & & 9 & & & & 11,0 & 87 \\
\hline & & 14399 & & 2,1 & 0,1 & 4 & 8 & & & & 4,3 & 1.372 \\
\hline & & $248 \quad 109$ & 947 & 1,4 & 0,9 & 3 & 5 & & & - & 12,3 & 203 \\
\hline & & $\begin{array}{ll}339 & 104\end{array}$ & & 1,5 & 1,2 & 5 & 17 & & & 5.949 & 19,1 & 3.50 \\
\hline & & $211 \quad 109$ & .922 & 1,5 & 0,9 & 5 & 6 & & & & 11,6 & 5.35 \\
\hline & & $\begin{array}{lll}195 & 106\end{array}$ & 151.664 & 1,7 & 0,5 & 7 & 17 & & & & 13,6 & 00.10 \\
\hline & & $149 \quad 98$ & 69.774 & 1,7 & 1,0 & 6 & 13 & & & & 9,7 & 12.66 \\
\hline & & $259 \quad 114$ & & 0,9 & 1,9 & 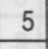 & 1 & & & 124.416 & 9,5 & 2.0 \\
\hline & & $328 \quad 106$ & .353 & 1,6 & 1,0 & 5 & 16 & & & 261 & 8,3 & 3.18 \\
\hline & & $264 \quad 113$ & .668 & 1,1 & 2,4 & 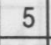 & 10 & & & & 7,4 & 0.04 \\
\hline Ptu. & & $200 \quad 112$ & 12.789 & 1,4 & 3,0 & 4 & 13 & & & 83.920 & 7,0 & 23 \\
\hline & 442 & $213 \quad 137$ & 8.180 & 1,8 & 1,1 & 3 & 7 & $10.2 \mathrm{N1}$ & & - & 7,9 & 1.65 \\
\hline & & $120 \quad 102$ & 8.952 & 1,9 & 0,1 & 4 & 6 & 21.542 & & 47.838 & 13,9 & 1.6 \\
\hline - & 27.337 & $\begin{array}{ll}488 & 119\end{array}$ & 18.932 & 1,6 & 0,6 & 4 & 2 & 20.070 & 37.671 & 38.818 & & . \\
\hline
\end{tabular}

Iz seznama je razvidno, da se je z dodajanjem bližnjih mestnih naselij uvrstil med mestne občine tudi Kamnik, povečala pa so svoje prebivalstvo mesta Domžale, Izola, Jesenice, Kranj, Ljubljana, Maribor, Nova Gorica, Ptuj in Škofja Loka. Ostala mesta, ki so takšno priključitev dejansko izvedla že prej, so glede na to ohranila dosedanje število prebivalstva (zaradi tega izkazujejo nekatera nesmiselno relativno rast, npr. Velenje, Koper). Rezultat točkovanja je bil naslednji: 
11 točk: Celje, Koper,

10 točk: Ljubljana, Nova Gorica,

9 točk: Kranj, Maribor, Velenje,

8 točk: Murska Sobota, Novo mesto, Ptuj,

7 točk: Domžale,

6 točk: Jesenice, Škofja Loka,

5 točk: Kamnik, Trbovlje,

2 točki: Izola.

C: Bolj zapletena je bila izvedba tretje možnosti, to je, da za vsa naselja v bližnji okolici mest določimo enotna merila in na njihovi podlagi opredelimo, katera naselja bi bilo treba vključiti $v$ mesto. Takšen poskus smo napravili in določili naslednje vrednosti kot opredelitvena merila.

Tabela 4: Merila za opredelitev naselij v neposredni mestni okolici, ki bi jih bilo mogoče glede na urbaniziranost in povezanost $\mathrm{z}$ mestom pridružiti $\mathrm{k}$ mestom

\begin{tabular}{|l|c|}
\hline Merilo & mejna vrednost \\
\hline $\begin{array}{l}\text { Razvoj prebivalstva: indeks 1991/1953 } \\
\text { indeks 1991/1981 }\end{array}$ & $\begin{array}{c}\text { ali }>130 \\
\text { Delež kmečkega prebivalstva v \% }\end{array}$ \\
\hline Delež aktivnih bivajočih, ki delajo v drugem kraju v občini v \% & $<7$ \\
\hline Koeficient med številom prebivalcev in zaposlenimi v naselju & $>62,5$ \\
\hline Gostota prebivalcev na ha (po popisu l. 1991) & $>2,2$ \\
\hline
\end{tabular}

Uporabljeni kazalci naj bi pokazali pretežno urbani značaj naselja (močnejša rast prebivalstva, večja gostota prebivalstva, nizek delež kmečkega prebivalstva), povezanost $\mathrm{z}$ mestom (visok delež v kraju bivajočih, ki delajo v drugem kraju v občini, to je v bližnjem mestu) in pretežno stanovanjski značaj naselja (koeficient med bivajočimi in zaposlenimi)

Na podlagi navedenih meril, ki so se večidel izkazala kot smiselna, smo lahko določili okoliška naselja, ki bi jih lahko vključili v sedanja mesta. To so bila:

Celje: Bukovžlak, Dobrovo, Košnica, Ljubečna, Lokrovec, Lopata, Osenca, Prekorje, Slance, Škofja vas, Šmarjeta pri Celju, Šmiklavž pri Škofji vasi, Teharje, Trnovlje pri Celju, Vrhe, Začret, Zadobrova in Zvodno.

Domžale: Podrečje, Rodica, Spodnje Jarše, Srednje Jarše, Vir, Zaboršt.

Izola: Jagodje.

Jesenice: Blejska Dobrava, Hrušica, Kočna, Lipce, Podkočna.

Kamnik: Duplica, Jeranovo, Mekinje, Nevlje, Oševek, Vrhpolje pri Kamniku.

Kočevje: Mahovnik, Šalka vas. 
Koper: Bertoki, Bošamarin, Kampel, Manžan, Prade, Šalara, Škocjan, (Triban).

Kranj: Breg ob Savi, Bobovek, Britof, Kokrica, Mlaka pri Kranju, Orehovlje, Predoslje.

Ljubljana: (Brezovica), Lavrica, Medno, Spodnje Gameljne, Stanežiče, Srednje Gameljne, (Vnanje Gorice), Zgornje Gameljne.

Maribor: Bistrica pri Limbušu, Bresternica, Celestrina, Čreta, Dobravce, Dogoše, Dravski Dvor, Hotinja vas, Hrenca, Jelovec, Kamnica, Košaki, Laznica, Limbuš, Malečnik, Meljski Hrib, Miklavž na Dravskem polju, (Orehova vas), Pekel, Pekre, Pivola, Počehova, Polana, Radizel, Razvanje, Ribniško selo, Rogoza, Skoke, Slivnica pri Mariboru, Spodnje Hoče, Trčova, Vinarje, Za Kalvarijo, Zgornje Hoče, Zrkovci.

Murska Sobota: Černelavci, Rakičan.

Nova Gorica: Kromberk, Pristava, Rožna Dolina, Solkan.

Novo mesto: Mala Cikava, Mali Slatnik, Prečna, Srebrniče.

Ptuj: Brstje, Budina, Krčevina pri Ptuju, Nova vas pri Ptuju, Orešje, Rabelčja vas,

Rogoznica, Spodnja Hajdina, Štuki, Vičava, Zgornja Hajdina, Žabjak.

Škofja Loka: Binkelj, Grenc, Hosta, Podpulfrca, Puštal, Stara Loka, Suha, Sveti Duh, (Trata), Vincarje, Virmaše.

Trbovlje: Gabersko, Ojstro.

Velenje: Bevče, Hrastovec, Paka pri Velenju, Podkraj pri Velenju, Škale.

Izvedena korektura je pokazala, da do večjih sprememb v sestavu mest z več kot 10.000 prebivalci ni prišlo - mednje sta se na novo uvrstila le Kočevje in Zagorje pač pa so se znatno zvečala srednje velika mesta in na tej osnovi so se spremenile tudi nekatere opredelitvene vrednosti, kar je pripomoglo k večji diferenciaciji med njimi, kot je to razvidno iz tabele. Meji 10.000 prebivalcev so se približala še nekatera naselja, kot npr. Slovenj Gradec, Ravne na Koroškem in Tržič. Presegla pa so to mejo somestja Piran-Portorož-Lucija in Ravne/K.-Prevalje.

Tabela 5: C: Seznam in razvrstitev mestnih občin ob vključitvi bližnjih, urbaniziranih in $\mathrm{z}$ mesti tesno povezanih naselij (po merilih in metodi avtorja)

\begin{tabular}{|c|c|c|c|c|c|c|c|c|c|c|c|c|}
\hline Mesto & $\begin{array}{c}\text { Prebi- } \\
\text { valstvo } \\
1991\end{array}$ & $\begin{array}{l}\text { Indeksi } \\
91 / 91 / \\
5381\end{array}$ & $\begin{array}{c}\text { Zapo- } \\
\text { sleni } \\
1991\end{array}$ & $\begin{array}{l}\mathrm{K} . \\
\mathrm{P} / \mathrm{z}\end{array}$ & $\begin{array}{l}\% \\
k p\end{array}$ & $\begin{array}{l}\mathrm{C} \\
\mathrm{n}\end{array}$ & $\begin{array}{l}\text { Št } \\
\text { f. }\end{array}$ & $\begin{array}{c}\text { Prebiv. } \\
\text { vicinal. } \\
\text { raven }\end{array}$ & $\begin{array}{l}\text { Prebiv. } \\
\text { mikror. } \\
\text { raven }\end{array}$ & $\begin{array}{l}\text { Prebiv. } \\
\text { mezor. } \\
\text { raven }\end{array}$ & $\begin{array}{l}\text { P/ } \\
\text { ha }\end{array}$ & $\begin{array}{c}\text { DP* } \\
1990\end{array}$ \\
\hline Celje & 48.085 & $\begin{array}{ll}196 & 107 \\
\end{array}$ & 30.352 & 1.5 & 0,5 & 5 & 15 & 48.811 & 88.068 & 208.490 & 17,2 & 6.319 \\
\hline Domžale & 16.232 & $298 \quad 110$ & 7.227 & 2.2 & 0,8 & 3 & 13 & 25.240 & 45.628 & - & 16,1 & 1.296 \\
\hline Izola & 12.083 & $150 \quad 102$ & 5.945 & 2.1 & 1,2 & 3 & 9 & 12.990 & 12.513 & - & 11,0 & 877 \\
\hline Jesenice & 21.877 & $142 \quad 99$ & 10.201 & 2.1 & 0,1 & 4 & 8 & 19.518 & 31.090 & 53.778 & 4,8 & 1.372 \\
\hline Kamnik & 13.963 & $238 \quad 108$ & 9.011 & 1.5 & 1,1 & 3 & 6 & 18.525 & 24.693 & - & 10,6 & 2.030 \\
\hline Kočevje & 10.304 & $196 \quad 100$ & 4.057 & 2.5 & 0,5 & 3 & 7 & 15.199 & 19.000 & - & 4,9 & 1.103 \\
\hline Koper & 28.142 & $172 \quad 106$ & 16.123 & 1,7 & 1,6 & 5 & 17 & 32.484 & 43.415 & 95.949 & 9,1 & 3.503 \\
\hline Kranj & 42.461 & $139 \quad 108$ & 26.958 & 1,5 & 0,8 & 5 & 6 & 57.915 & 67.567 & 117.174 & 10,9 & 5.355 \\
\hline
\end{tabular}




\begin{tabular}{|l|r|rr|r|r|r|r|r|r|r|r|r|r|}
\hline Ljubljana & 278.924 & 202 & 108 & 151.766 & 1,8 & 0,5 & 7 & 17 & 234.229 & 298.411 & 489.292 & 15,1 & 33.767 \\
\hline Maribor & 131.707 & 152 & 99 & 69.962 & 1,8 & 0,6 & 6 & 13 & 109.569 & 182.333 & 257.988 & 9,7 & 12.668 \\
\hline M. Sobota & 16.568 & 244 & 113 & 15.724 & 1,0 & 2,9 & 5 & 7 & 35.592 & 62.688 & 124.416 & 6,4 & 2.668 \\
\hline N. Gorica & 20.753 & 328 & 106 & 12.353 & 1,6 & 1,0 & 5 & 16 & 36.928 & 48.016 & 118.261 & 8,3 & 3.184 \\
\hline N. mesto & 23.149 & 261 & 112 & 19.822 & 1,1 & 2,5 & 5 & 10 & 32.585 & 52.063 & 96.750 & 6,4 & 3.801 \\
\hline Ptuj & 20.314 & 195 & 114 & 13.032 & 1,5 & 3,7 & 4 & 13 & 38.632 & 68.020 & 83.920 & 6,7 & 2.352 \\
\hline Šk. Loka & 16.210 & 209 & 120 & 7.196 & 2,2 & 1,2 & 3 & 7 & 16.297 & 30.353 & - & 7,7 & 1.656 \\
\hline Trbovlje & 17.994 & 119 & 102 & 9.201 & 1,9 & 0,1 & 4 & 6 & 21.542 & 21.542 & 47.838 & 11,1 & 1.685 \\
\hline Velenje & 29.198 & 488 & 119 & 18.895 & 1,5 & 0,5 & 4 & 2 & 28.076 & 37.671 & 38.818 & 11,2 & 3.975 \\
\hline Zagorje & 10.309 & 141 & 102 & 3.800 & 2,7 & 0,6 & 3 & 5 & 13.738 & 16.494 & - & 5,7 & 445 \\
\hline
\end{tabular}

* S podrobnimi podatki o družbenem proizvodu po posameznih naseljih ne razpolagamo, vendar je velika verjetnost, da se bistveno ne razlikujejo od podatkov v varianti B; zato smo jih tudi uporabili.

Tabela 6: Razvrstitev mest $\mathrm{z}$ več kot 10.000 prebivalci glede na variante $\mathrm{A}, \mathrm{B}$ in $\mathrm{C}$.

\begin{tabular}{|c|c|c|c|}
\hline $\begin{array}{l}\text { toč- } \\
\text { ke }\end{array}$ & $\begin{array}{l}\text { Varianta A - zgolj } \\
\text { sedanje mestno ozemlje }\end{array}$ & $\begin{array}{l}\text { Varianta B: mesta + "mestna } \\
\text { naselja" (Zavod za statistiko) }\end{array}$ & $\begin{array}{l}\text { Varianta C: mesta + dodana } \\
\text { urbanizirana naselja (Vrišer) }\end{array}$ \\
\hline 11 & Celje, Koper, Ljubljana & Celje, Koper & Ljubljana, Celje \\
\hline 10 & Nova Gorica & Ljubljana, Nova Gorica & Koper, Nova Gorica \\
\hline 9 & Kranj, Maribor, Velenje & Kranj, Maribor, Velenje & Kranj, Maribor \\
\hline 8 & $\begin{array}{l}\text { Murska Sobota, Novo } \\
\text { mesto }\end{array}$ & $\begin{array}{l}\text { Murska Sobota, Novo mesto, } \\
\text { Ptuj }\end{array}$ & Novo mesto, Ptuj, Velenje \\
\hline 7 & Ptuj, Jesenice & Domžale & Domžale, Murska Sobota \\
\hline 6 & Domžale, Škofja Loka & Jesenice, Škofja Loka & Jesenice \\
\hline 5 & Trbovlje & Kamnik, Trbovlje & $\begin{array}{l}\text { Kamnik, Škofja Loka, } \\
\text { Trbovlje }\end{array}$ \\
\hline 4 & & - & - \\
\hline 3 & Izola & - & - \\
\hline 2 & & Izola & Izola, Kočevje, Zagorje \\
\hline
\end{tabular}

Kot pri vsakem točkovanju, so tudi v tem primeru nekateri kazalci pri posameznih mestih izjemno nizki in znižujejo končni seštevek ter potiskajo mesto navzdol. Kot primer navajamo:

- rast prebivalstva: Izola, Jesenice, Maribor, Trbovlje, Zagorje;

- visok delež kmečkega prebivalstva: Murska Sobota, Novo mesto, Ptuj:

- neugodno razmerje med bivajočim prebivalstvom in zaposlenimi: Domžale, Izola, Kočevje, Zagorje;

- število nadpovprečno razvitih mestnih funkcij: Jesenice, Kranj, Kamnik, Škofja Loka, Trbovlje, Velenje;

- majhno vplivno območje: Izola, Trbovlje;

- nizka gostota prebivalstva: Jesenice, Kočevje, Murska Sobota, Novo mesto, Ptuj, Škofja Loka, Zagorje; 
- nizka vrednost ustvarjenega družbenega proizvoda: Domžale, Izola, Jesenice, Kamnik, Kočevje, Murska Sobota, Ptuj, Škofja Loka, Trbovlje.

\section{MERILA ZA OPREDELITEV NASELIJ, KI BI IZPOLNJEVALA POGOJE ZA DODELITEV NASLOVA "MESTO"}

Postopek, ki smo ga uporabili pri tehtanju dodelitve naslova "mesto" posameznim naseljem, je podoben tistemu, s katerim smo izbirali in vrednotili morebitno podelitev naziva "mestna občina". Omilili smo le kriterije oziroma dodali nove, manj zahtevne, saj so bila prizadeta naselja manjša in z manj izrazitim urbanim značajem

Pri določanju meril smo si pomagali z vrednostmi, ki smo jih izračunali za celo Slovenijo in sicer: za "mesta in mestna naselja", za 47 mest (po seznamu mest iz l. 1952, vendar brez Bovca, Kostanjevice, Radeč in Višnje Gore), posebej za Ljubljano in Maribor, za 45 mest (brez Ljubljane in Maribora) ter za ostala naselja. Rezultati, ki smo jih dobili in so prikazani v tabeli, so pomagali pri presoji, kje postaviti spodnjo mejo za posamezni kazalec "urbanosti".

Tabela 7: Kazalci o urbanem značaju slovenskih mest in drugih naselij

\begin{tabular}{|l|r|r|r|r|r|r|}
\hline Merila & $\begin{array}{r}\text { Republika } \\
\text { Slovenija }\end{array}$ & $\begin{array}{c}\text { Mesta in } \\
\text { mestna } \\
\text { naselja }\end{array}$ & $\begin{array}{r}\text { Mesta (47 } \\
\text { po številu) }\end{array}$ & $\begin{array}{r}\text { Ljubljana } \\
\text { in Maribor }\end{array}$ & $\begin{array}{r}\text { Mesta brez } \\
\text { Lj. in Mb. }\end{array}$ & $\begin{array}{r}\text { Ostala } \\
\text { naselja }\end{array}$ \\
\hline Prebivalstvo leta: & 1.965 .986 & 993.049 & 814.022 & 379.967 & 434.055 & 972.937 \\
1991 & 1.891 .864 & 925.532 & 734.573 & 330.930 & 403.643 & 966.332 \\
1981 & 1.504 .427 & 497.551 & 415.607 & 207.087 & 208.520 & 1.006 .876 \\
1953 & 130,6 & 199,5 & 195,8 & 183,4 & 208,1 & 100,6 \\
\hline Indeks razvoja preb.: & 103,9 & 107,2 & 110,8 & 114,8 & 107,5 & 96,6 \\
$1991: 1953$ & 878.789 & 606.699 & 535.658 & 217.081 & 318.577 & 272.090 \\
$1991: 1981$ & 2,23 & 1,63 & 1,51 & 1,75 & 1,36 & 3,57 \\
\hline Zaposleni: število & 145.422 & 10.511 & 5.850 & 1.844 & 4.006 & 134.911 \\
\hline Bivajoči / zaposleni & 1,39 & 1,05 & 0,72 & 0,44 & 0,92 & 13,86 \\
\hline Kmečko prebivalstvo \\
\% kmeckega prebiv.
\end{tabular}


Na podlagi teh kazalcev smo pripravili mejne vrednosti o "urbanosti" posameznih naselij z več kot 2000 prebivalci in izračunali, kolikokrat je naselje preseglo spodnjo mejno vrednost. Vsakemu takšnemu primeru smo pripisali vrednost ene oziroma dveh točk; skupni maksimalni zbir je znašal 18 točk.

Tabela 8: Mejne vrednosti pri opredelitvi naselij z več kot 2000 prebivalci, ki naj bi imela značaj in naslov "mesta"

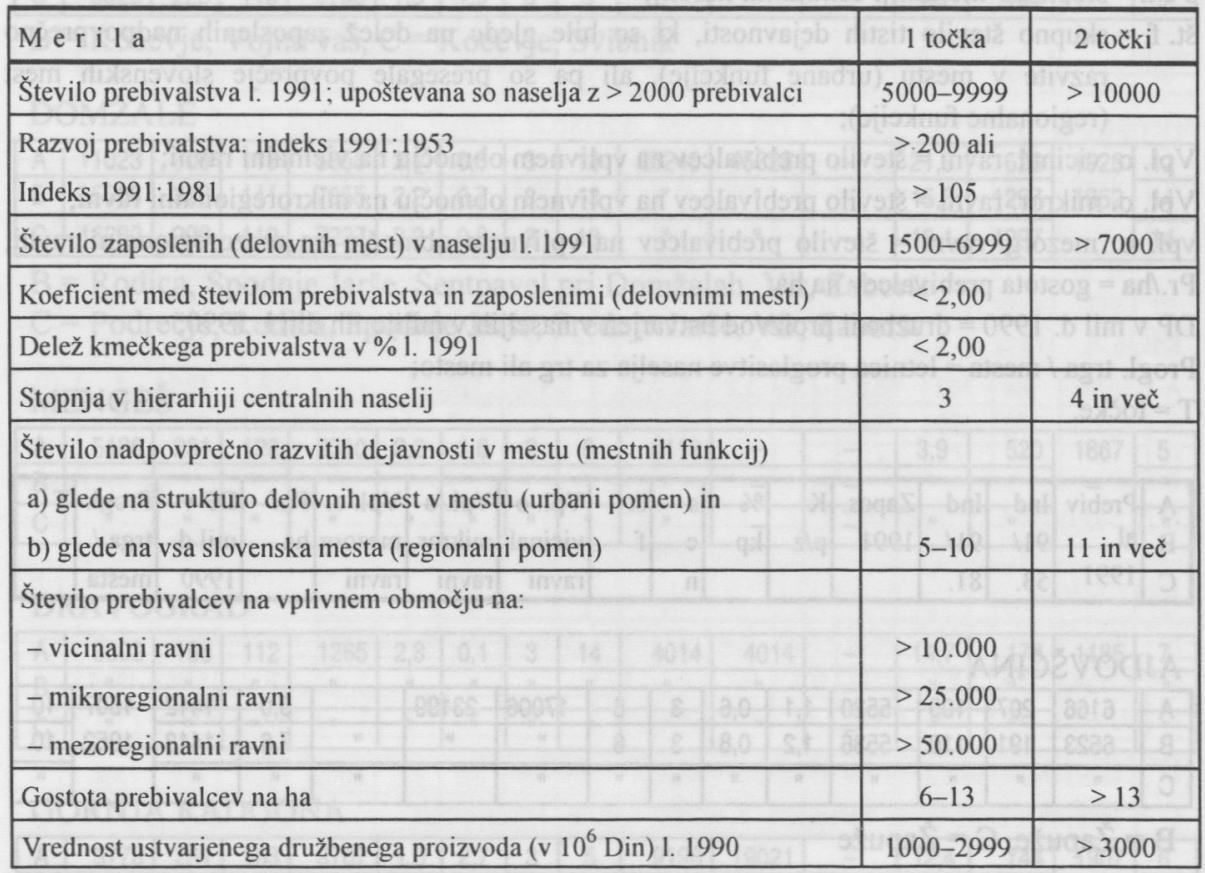

Tabela 9: Opredelitev mest v Republiki Sloveniji glede na izbrana merila (po merilih $\mathrm{v}$ tabeli 8 )

$A=$ upoštevano je zgolj imenovano naselje,

$\mathrm{B}=$ upoštevano je imenovano naselje in bližnja mestna naselja (po opredelitvi republiškega zavoda za statistiko),

$\mathrm{C}=$ upoštevano je imenovano naselje in bližnja $\mathrm{z}$ mestom tesno povezana in urbanizirana naselja po opredelitvi avtorja razprave. 


\section{Legenda:}

Preb. 1991 = število prebivalcev 1. 1991;

Ind $91 / 53$ = indeks razvoja prebivalstva med 1.1953 in 1991,

Ind $91 / 81$ = indeks razvoja prebivalstva med 1. 1991 in 1981;

Zapos. = število zaposlenih (delovnih mest 1. 1991);

$\mathrm{K}=$ koeficient med številom prebivalstva in zaposlenimi;

$\%$ k.p = delež kmečkega prebivalstva;

s c n = stopnja $v$ hierarhiji centralnih naselij;

št. f. = skupno število tistih dejavnosti, ki so bile glede na delež zaposlenih nadpovprečno razvite $v$ mestu (urbane funkcije), ali pa so presegale povprečje slovenskih mest (regionalne funkcije);

Vpl. o. vicinal. ravni = število prebivalcev na vplivnem območju na vicinalni ravni;

Vpl. o. mikror. ravni = število prebivalcev na vplivnem območju na mikroregionalni ravni;

vpl. o. mezorg. ravni = število prebivalcev na vplivnem območju na mezoregionalni ravni; $\operatorname{Pr} . /$ ha $=$ gostota prebivalcev na ha;

DP v mil d. 1990 = družbeni proizvod ustvarjen v naseljih v milijonih din 1. 1990;

Progl. trga / mesta = letnica proglasitve naselja za trg ali mesto;

$\mathrm{T}=$ točke.

\begin{tabular}{|c|c|c|c|c|c|c|c|c|c|c|c|c|c|c|c|}
\hline A & Prebiv & Ind & Ind & Zapos. & $\mathrm{K}$ & $\%$ & s & št & Vpl. o & Vpl. o & Vpl. o. & Pr.I & DP v & Progl. & $\mathrm{T}$ \\
\hline B & & $91 /$ & $91 /$ & 1991 & $\mathrm{p} / \mathrm{z}$ & $\mathrm{kp}$ & c & f & vicinal & mikror. & mezorg & ha & mil d. & trga / & \\
\hline $\mathrm{C}$ & 1991 & 53. & 81. & & & & n & & ravni & ravni & ravni & & 1990 & mesta & \\
\hline
\end{tabular}

\section{AJDOVŠČINA}

\begin{tabular}{|c|c|c|c|c|c|c|c|c|c|c|c|c|c|c|c|}
\hline A & 6166 & 207 & 109 & 5520 & 1,1 & 0,6 & 3 & 6 & 17006 & 23199 & - & 9,0 & 1412 & 1507 & 10 \\
\hline B & 6523 & 191 & 110 & 5536 & 1,2 & 0,8 & 3 & 6 & $"$ & $"$ & $"$ & 7,6 & 1413 & 1952 & 10 \\
\hline C & $" \prime$ & $"$ & $"$ & $"$ & $"$ & $"$ & $"$ & $"$ & $"$ & & $"$ & $"$ & $"$ & & \\
\hline
\end{tabular}

B = Žapuže, $\mathrm{C}=$ Žapuže

\section{BREŽICE}

\begin{tabular}{|c|c|c|c|c|c|c|c|c|c|c|c|c|c|c|c|}
\hline A & 6856 & 183 & 123 & 2717 & 2,5 & 2,7 & 4 & 13 & 16277 & 26669 & 56199 & 7,7 & 650 & \multirow{3}{*}{$\begin{array}{l}\text { 13. st } \\
1322\end{array}$} & 11 \\
\hline$B$ & $"$ & $"$ & " & $"$ & " & " & " & $"$ & " & $"$ & " & $"$ & " & & $n$ \\
\hline C & " & " & " & " & " & " & " & " & " & " & " & " & " & & " \\
\hline
\end{tabular}

\section{CELJE}

\begin{tabular}{|c|c|c|c|c|c|c|c|c|c|c|c|c|c|c|c|}
\hline A & 40710 & 214 & 107 & 29131 & 1,4 & 0,7 & 5 & 15 & 48801 & 88068 & 208490 & 17,1 & 6319 & 1323 & 18 \\
\hline B & $"$ & $"$ & " & $"$ & $"$ & " & " & " & " & $"$ & $"$ & $"$ & $"$ & 1451 & " \\
\hline C & 48085 & 196 & 107 & 30352 & 1,5 & 0,5 & " & " & " & $"$ & $"$ & 7,2 & $"$ & & 17 \\
\hline
\end{tabular}

C = Bukovžlak, Dobrova, Košnica, Leskovec, Ljubečna, Lokrovec, Lopata, Osenca, Prekorje, Slance, Škofja vas, Šmarjeta pri Celju, Šmiklavž pri Škofji vasi, Teharje, Tremerje, Trnovlje, Vrhe, Začret, Zadobrovo, Zvodno 


\section{CERKNICA}

\begin{tabular}{|c|c|c|c|c|c|c|c|c|c|c|c|c|c|c|c|}
\hline A & 3455 & 245 & 114 & 1697 & 2,0 & 1,4 & 3 & 9 & 6660 & 13100 & - & 2,3 & 418 & ? & 5 \\
\hline B & " & $"$ & " & " & " & $"$ & $"$ & $"$ & " & $"$ & - & " & " & - & " \\
\hline C & " & " & " & $"$ & " & $"$ & $"$ & " & " & " & - & $"$ & " & & " \\
\hline
\end{tabular}

\section{ČRNOMELJ}

\begin{tabular}{|c|c|c|c|c|c|c|c|c|c|c|c|c|c|c|c|}
\hline A & 5462 & 229 & 115 & 3738 & 1,5 & 1,1 & 3 & 9 & 10282 & 15847 & - & 4,7 & 435 & 1277 & 9 \\
\hline$B$ & 5817 & 223 & 115 & 3792 & 1,5 & 2,0 & 3 & 9 & $"$ & $"$ & - & 4,3 & 458 & 1407 & 8 \\
\hline C & 5825 & 225 & 116 & 3790 & 1,5 & 1,9 & 3 & 9 & $"$ & $"$ & - & 4,2 & 458 & & 9 \\
\hline
\end{tabular}

B = Kočevje, Vojna vas, C = Kočevje, Svibnik

DOMŽALE

\begin{tabular}{|r|r|r|r|r|r|r|r|r|c|c|c|c|r|r|r|}
\hline A & 11023 & 309 & 113 & 5358 & 2,1 & 0,8 & 3 & 13 & 25240 & 45628 & - & 21,3 & 626 & 1925 & 12 \\
\hline B & 15506 & 378 & 141 & 7055 & 2,2 & 0,7 & 3 & 13 & $n$ & $"$ & - & 15,8 & 1297 & 1952 & 14 \\
\hline C C & 16232 & 298 & 110 & 7227 & 2,2 & 0,8 & 3 & 13 & $"$ & $"$ & - & 16,1 & 1297 & & 14 \\
\hline
\end{tabular}

B = Rodica, Spodnje Jarše, Šentpavel pri Domžalah, Vir, Zaboršt

C = Podrečje, Rodica, Spodnje Jarše, Srednje Jarše, Vir, Zaboršt

\section{MENGEŠ}

\begin{tabular}{|c|c|c|c|c|c|c|c|c|c|c|c|c|c|c|c|}
\hline A & 5186 & 231 & 126 & 2310 & 2,2 & 1,6 & 2 & 6 & 6113 & - & - & 3,9 & 520 & \multirow{3}{*}{$\begin{array}{c}1867 \\
-\end{array}$} & 5 \\
\hline$B$ & " & $"$ & " & " & " & $"$ & $"$ & " & " & - & - & " & " & & " \\
\hline C & " & " & " & " & $"$ & $"$ & $"$ & " & " & - & - & $"$ & $"$ & & " \\
\hline
\end{tabular}

\section{DRAVOGRAD}

\begin{tabular}{|c|c|c|c|c|c|c|c|c|c|c|c|c|c|c|c|}
\hline A & 3502 & 198 & 112 & 1265 & 2,8 & 0,1 & 3 & 14 & 4014 & 4014 & - & 14,7 & 178 & 1185 & 7 \\
\hline B & " & $"$ & $"$ & " & $"$ & $"$ & " & $"$ & $"$ & $"$ & - & $"$ & " & - & " \\
\hline C & " & $n$ & " & $"$ & $"$ & " & " & " & " & " & - & " & " & 10 & $"$ \\
\hline
\end{tabular}

GORNJA RADGONA

\begin{tabular}{|c|c|c|c|c|c|c|c|c|c|c|c|c|c|c|c|}
\hline A & 3778 & 281 & 103 & 3707 & 1,0 & 2,7 & 3 & 5 & 9198 & 19021 & - & 12,4 & 744 & 1907 & 6 \\
\hline$B$ & $"$ & $"$ & $"$ & " & $"$ & $"$ & $"$ & $"$ & $"$ & $"$ & - & " & " & 1952 & $"$ \\
\hline C & $"$ & $"$ & $"$ & $"$ & $"$ & $"$ & $"$ & $"$ & $"$ & " & - & $"$ & $"$ & & $"$ \\
\hline
\end{tabular}

\section{RADENCI}

\begin{tabular}{|c|c|c|c|c|c|c|c|c|c|c|c|c|c|c|c|}
\hline A & 2215 & 430 & 117 & 1151 & 1,9 & 1,6 & 2 & 6 & 5018 & 1635 & - & 7,3 & 324 & - & 5 \\
\hline$B$ & " & $"$ & " & " & $"$ & $"$ & " & $"$ & $"$ & $"$ & - & $"$ & " & - & " \\
\hline C & " & " & $"$ & " & " & " & $"$ & $"$ & " & " & - & $"$ & " & - & $"$ \\
\hline
\end{tabular}

GROSUPLJE

\begin{tabular}{|c|c|c|c|c|c|c|c|c|c|c|c|c|c|c|c|}
\hline A & 5522 & 495 & 125 & 3330 & 1,6 & 1,2 & 3 & 10 & 10681 & 15376 & - & 10,5 & 496 & - & 9 \\
\hline B & 5602 & 469 & 124 & 3384 & 1,6 & 1,6 & 3 & 10 & 10661 & 15376 & - & 9,6 & 568 & - & 9 \\
\hline $\mathrm{C}$ & " & $"$ & $"$ & " & $"$ & $n$ & " & " & $"$ & $"$ & - & $n$ & " & - & " \\
\hline
\end{tabular}

$\mathrm{B}=$ Brvace, $\mathrm{C}=$ Brvace 
HRASTNIK

\begin{tabular}{|c|c|c|c|c|c|c|c|c|c|c|c|c|c|c|c|}
\hline A & 6673 & 129 & 102 & 3949 & 1,7 & 0,1 & 3 & 5 & 8038 & 8268 & - & 11,6 & 667 & - & 7 \\
\hline B & $"$ & $"$ & $"$ & $"$ & $"$ & $"$ & $"$ & $"$ & $"$ & $"$ & - & $"$ & $"$ & 1952 & $"$ \\
\hline C & 8508 & 148 & 101 & 4350 & 1,9 & 0,3 & 3 & 5 & $"$ & $"$ & - & 7,1 & 667 & & 7 \\
\hline
\end{tabular}

$\mathrm{C}=$ Brnica, Dol

IDRIJA

\begin{tabular}{|c|c|c|c|c|c|c|c|c|c|c|c|c|c|c|c|}
\hline A & 6171 & 123 & 90 & 3178 & 1,9 & 0,2 & 3 & 10 & 9996 & 14115 & - & 4,7 & 583 & 17. st & 7 \\
\hline$B$ & " & " & " & " & $"$ & $"$ & " & " & " & " & - & " & " & $?$ & " \\
\hline C & $"$ & " & " & $"$ & " & " & $n$ & " & " & $"$ & - & " & " & & $"$ \\
\hline
\end{tabular}

ILIRSKA BISTRICA

\begin{tabular}{|c|c|c|c|c|c|c|c|c|c|c|c|c|c|c|c|}
\hline A & 4880 & 134 & 101 & 3023 & 1,6 & 1,0 & 3 & 9 & 11899 & 15287 & - & 1,4 & 635 & \multirow{3}{*}{$\begin{array}{l}1911 \\
1932\end{array}$} & 6 \\
\hline B & $"$ & $"$ & " & $"$ & $"$ & $"$ & $"$ & $"$ & $"$ & $"$ & - & $"$ & " & & " \\
\hline $\mathrm{C}$ & " & " & " & " & $"$ & $"$ & " & " & " & $"$ & - & $"$ & " & & $"$ \\
\hline
\end{tabular}

\section{IZOLA}

\begin{tabular}{|c|c|c|c|c|c|c|c|c|c|c|c|c|c|c|c|}
\hline A & 10284 & 164 & 103 & 5519 & 1,9 & 1,2 & 3 & 9 & 12900 & 12513 & - & 13,8 & 860 & ? & 10 \\
\hline$B$ & 12119 & 186 & 120 & 5945 & 2,0 & 1,2 & 3 & 9 & " & $"$ & - & 11,1 & 877 & ? & 9 \\
\hline C & " & " & $"$ & " & " & " & " & " & " & " & - & " & " & & " \\
\hline
\end{tabular}

B = Jagodje C = Jagodje

JESENICE

\begin{tabular}{|c|c|r|r|r|r|r|r|c|c|c|c|c|c|c|c|}
\hline A & 18807 & 142 & 95 & 9815 & 1,9 & 0,1 & 4 & 6 & 19518 & 31090 & 53788 & 6,8 & 1309 & 14. st & 14 \\
\hline B & 21702 & 143 & 99 & 10190 & 2,1 & 0,1 & 4 & 6 & $"$ & $"$ & $"$ & 4,9 & 1489 & 1929 & 12 \\
\hline C C & 21877 & 142 & 99 & 10201 & 2,1 & 0,1 & 4 & 6 & $"$ & $"$ & $"$ & 4,8 & 2500 & & 12 \\
\hline
\end{tabular}

B = Blejska Dobrava, Hrušica, Kočna, Podkočna

C = Blejska Dobrava, Hrušica, Kočna, Lipce, Podkočna

\section{KAMNIK}

\begin{tabular}{|c|c|c|c|c|c|c|c|c|c|c|c|c|c|c|c|}
\hline A & 9695 & 255 & 116 & 7766 & 1,2 & 0,7 & 3 & 5 & 18125 & 24693 & - & 11,3 & 1718 & 1188 & 11 \\
\hline B & 12988 & 248 & 109 & 8947 & 1,5 & 0,9 & 3 & & " & " & - & 12,3 & 2030 & 1267 & 12 \\
\hline C & 13963 & 238 & 108 & 9011 & 1,5 & 1,1 & 3 & 5 & " & " & & 10,6 & " & & 12 \\
\hline
\end{tabular}

$\mathrm{B}=$ Duplica, Jeranovo, Mekinje

C = Duplica, Jeranovo, Mekinje, Nevlje, Oševek, Vrhpolje

\section{KOČEVJE}

\begin{tabular}{|c|r|r|r|r|r|r|r|c|c|c|c|c|c|c|c|}
\hline A & 9265 & 208 & 100 & 5596 & 1,7 & 0,5 & 3 & 6 & 15199 & 19000 & - & 6,5 & 1089 & 1377 & 10 \\
\hline B & 9958 & 198 & 100 & 5654 & 1,8 & 0,5 & 3 & 6 & $"$ & $"$ & - & 6,3 & 1102 & 1471 & 9 \\
\hline C & 10304 & 196 & 100 & 5715 & 1,5 & 0,5 & 3 & 6 & $"$ & $"$ & - & 4,9 & 1102 & & 9 \\
\hline
\end{tabular}

$\mathrm{B}=$ Šalka vas, $\mathrm{C}=$ Mahovnik, Šalka vas 
KOPER

\begin{tabular}{|c|c|c|c|c|c|c|c|c|c|c|c|c|c|c|c|}
\hline A & 24704 & 339 & 104 & 15529 & 1,3 & 1,2 & 5 & 17 & 32484 & 43415 & 95949 & 19,1 & 3503 & ? & 18 \\
\hline B & $"$ & $"$ & $"$ & $"$ & " & $"$ & $"$ & " & $"$ & $"$ & $"$ & $"$ & " & \multirow[t]{2}{*}{$4-5 \mathrm{st}$} & " \\
\hline C & 28042 & 172 & 106 & 16123 & 1,7 & 1,6 & 5 & 17 & $"$ & " & " & 9,1 & 3503 & & 17 \\
\hline
\end{tabular}

C = Bertoki, Bošamarin, Kampel, Manžan, Prade, Šalara, Škocjan, Triban

\section{KRANJ}

\begin{tabular}{|c|c|c|c|c|c|c|c|c|c|c|c|c|c|c|c|}
\hline $\mathrm{A}$ & 36456 & 204 & 108 & 26295 & 1,4 & 0,8 & 5 & 6 & 57915 & 67567 & 117174 & 13,8 & 5280 & $?$ & 17 \\
\hline $\mathrm{B}$ & 41978 & 211 & 109 & 26922 & 1,6 & 0,9 & 5 & 6 & $"$ & $"$ & $"$ & 11,6 & 5355 & 1221 & 16 \\
\hline $\mathrm{C}$ & 42461 & 139 & 108 & 26958 & 1,6 & 0,8 & 5 & 6 & $"$ & $"$ & $"$ & 10,9 & 5355 & & 16 \\
\hline
\end{tabular}

$\mathrm{C}=$ Breg ob Savi, Bobovek, Britof, Kokrica, Mlaka pri Kranju, Orehovlje, Predoslje

\section{KRŠKO}

\begin{tabular}{|c|c|c|c|c|c|c|c|c|c|c|c|c|c|c|c|}
\hline A & 7085 & 268 & 111 & 7256 & 1,0 & 2,4 & 3 & 11 & 15555 & 26148 & - & 11,8 & 1267 & $14 . \mathrm{st}$ & 12 \\
\hline B & 8033 & 239 & 111 & 7537 & 1,0 & 2,6 & 3 & 11 & $"$ & $"$ & - & 7,5 & 1273 & 1477 & 12 \\
\hline C & 8263 & 239 & 111 & 7550 & 1,1 & 2,8 & 3 & 11 & $"$ & $"$ & - & 6,8 & 1273 & & 12 \\
\hline
\end{tabular}

$\mathrm{B}=$ Leskovec pri Krškem, C = Kremen, Leskovec pri Krškem

\section{SENOVO}

\begin{tabular}{|c|c|c|c|c|c|c|c|c|c|c|c|c|c|c|c|}
\hline $\mathrm{A}$ & 2531 & 139 & 112 & 1282 & 2,0 & 3,8 & 2 & 2 & 5966 & - & - & 7,7 & 106 & - & 2 \\
\hline $\mathrm{B}$ & $"$ & $"$ & $"$ & $"$ & $"$ & $"$ & $"$ & $"$ & $"$ & - & - & $"$ & $"$ & - & $"$ \\
\hline $\mathrm{C}$ & $"$ & $"$ & $"$ & $"$ & $"$ & $"$ & " & $"$ & $"$ & - & - & $"$ & $"$ & & $"$ \\
\hline
\end{tabular}

LAŠKO

\begin{tabular}{|c|c|c|c|c|c|c|c|c|c|c|c|c|c|c|c|}
\hline A & 3641 & 241 & 157 & 2106 & 1,7 & 0,8 & 3 & 8 & 9524 & 10073 & - & 11,3 & 489 & 1227 & 7 \\
\hline$B$ & $"$ & " & " & $"$ & $"$ & " & $"$ & " & $"$ & " & - & " & " & 1927 & $"$ \\
\hline C & 4451 & 211 & 144 & 2159 & 2,0 & 1,3 & 3 & 8 & $"$ & $"$ & - & 6,6 & 489 & & 6 \\
\hline
\end{tabular}

$\mathrm{C}=$ Jagoče, Marija Gradec, Strmca

\section{RADEČE}

\begin{tabular}{|c|c|c|c|c|c|c|c|c|c|c|c|c|c|c|c|}
\hline A & 2452 & 193 & 132 & 1222 & 2,0 & 0,4 & 2 & 2 & 6232 & - & - & 8,4 & 932 & $?$ & 3 \\
\hline B & " & " & " & " & " & $"$ & " & $"$ & " & - & - & $"$ & " & 1952 & $"$ \\
\hline C & 2576 & 175 & 144 & 1788 & 1,4 & 0,4 & 2 & 2 & " & - & - & 7,6 & 932 & & 5 \\
\hline
\end{tabular}

$$
\mathrm{C}=\text { Njivice }
$$

\section{LENART}

\begin{tabular}{|c|c|c|c|c|c|c|c|c|c|c|c|c|c|c|c|}
\hline A & 2531 & 126 & 101 & 2489 & 1,5 & 3,3 & 3 & 5 & 12659 & 11779 & - & 4,0 & 304 & \multirow{3}{*}{ 15. st } & 5 \\
\hline$B$ & $"$ & $"$ & $"$ & $"$ & $"$ & & $"$ & $"$ & $"$ & $"$ & - & " & " & & $"$ \\
\hline C & $"$ & $"$ & " & " & $"$ & & $"$ & $"$ & " & " & - & $"$ & " & & " \\
\hline
\end{tabular}


LENDAVA

\begin{tabular}{|c|c|c|c|c|c|c|c|c|c|c|c|c|c|c|c|}
\hline $\mathrm{A}$ & 3807 & 152 & 103 & 3533 & 1,1 & 1,1 & 3 & 7 & 11782 & 19325 & - & 6,7 & 944 & 1366 & 7 \\
\hline $\mathrm{B}$ & 4571 & 138 & 102 & 3732 & 1,2 & 2,8 & 3 & 7 & $"$ & $"$ & - & 2,9 & 954 & 1952 & 5 \\
\hline C C & 4315 & 144 & 104 & 3808 & 1,2 & 1,8 & 3 & 7 & $"$ & $"$ & - & 5,1 & 954 & & 6 \\
\hline
\end{tabular}

$\mathrm{B}=$ Dolga vas, $\mathrm{C}=$ Lendavske Gorice

LITIJA

\begin{tabular}{|c|c|c|c|c|c|c|c|c|c|c|c|c|c|c|c|}
\hline A & 6540 & 236 & 116 & 2581 & 2,5 & 0,7 & 3 & 10 & 12840 & 16877 & - & 12,3 & 326 & 13. st & 8 \\
\hline B & 7930 & 214 & 124 & 3696 & 2,1 & 0,8 & 3 & 10 & " & " & - & 10,0 & 550 & 1952 & 8 \\
\hline C & $"$ & $"$ & $"$ & $"$ & $"$ & $"$ & " & " & " & " & - & $"$ & " & & " \\
\hline
\end{tabular}

$\mathrm{B}=$ Šmartno pri Litiji, C $=$ Šmartno pri Litiji

LJUBLJANA

\begin{tabular}{|c|c|c|c|c|c|c|c|c|c|c|c|c|c|c|c|}
\hline A & 267008 & 195 & 118 & 151153 & 1,8 & 0,5 & 7 & 17 & 234299 & 298411 & 489292 & 16,3 & 33626 & ? & 18 \\
\hline B & 270511 & 195 & 106 & 151664 & 1,8 & 0,5 & 7 & 17 & " & " & " & 13,6 & 33767 & 1220 & 18 \\
\hline C & 278924 & 202 & 108 & 151766 & 1,8 & 0,5 & 7 & 17 & " & " & " & 15,1 & 33767 & & 18 \\
\hline
\end{tabular}

B = Črna vas, Dvor, Lavrica, Lipe, Medno, Orle, Podgrad, Podmolnik, Stanežiče;

C = Lavrica, Medno, Spodnje Gameljne, Stanežiče, Srednje Gameljne, Zgornje

Gameljne

\section{MEDVODE}

\begin{tabular}{|c|c|c|c|c|c|c|c|c|c|c|c|c|c|c|c|}
\hline A & 4655 & 330 & 112 & 2353 & 1,9 & 0,5 & 2 & 2 & 11486 & - & - & 11,1 & 1038 & - & 7 \\
\hline B & 6004 & 262 & 112 & 2723 & 2,2 & 0,9 & 2 & 2 & $n$ & - & - & 8,1 & 1246 & - & - \\
\hline C & 6414 & 252 & 112 & 2872 & 2,2 & 1,0 & 2 & 2 & $n$ & - & - & 7,0 & 1246 & & 7 \\
\hline
\end{tabular}

$\mathrm{B}=$ Goričane, Ladja, Spodnja Senica, Vaše

$\mathrm{C}=$ Goričane, Ladja, Seničica, Spodnja Senica, Vaše, Zgornja Senica

\section{LJUTOMER}

\begin{tabular}{|c|c|c|c|c|c|c|c|c|c|c|c|c|c|c|c|}
\hline A & 3651 & 332 & 110 & 4158 & 0,9 & 3,4 & 3 & 7 & 14915 & 20762 & - & 4,5 & 557 & 1265 & 6 \\
\hline B & $"$ & $"$ & $"$ & $"$ & $"$ & $"$ & $"$ & $"$ & $"$ & $"$ & - & $"$ & $"$ & 1927 & " \\
\hline C & $"$ & " & " & " & " & " & " & " & " & $"$ & - & $"$ & $"$ & & " \\
\hline
\end{tabular}

\section{LOGATEC}

\begin{tabular}{|c|c|c|c|c|c|c|c|c|c|c|c|c|c|c|c|}
\hline $\mathrm{A}$ & 6411 & 258 & 123 & 2722 & 2,3 & 2,3 & 3 & 5 & 8030 & 8030 & - & 1,6 & 536 & - & 5 \\
\hline $\mathrm{B}$ & " & " & " & " & " & " & " & " & " & " & - & $"$ & " & - & - \\
\hline $\mathrm{C}$ & " & " & " & " & " & " & " & " & " & " & - & " & " & & " \\
\hline
\end{tabular}

\section{MARIBOR}

\begin{tabular}{|c|c|c|c|c|c|c|c|c|c|c|c|c|c|c|c|}
\hline A & 103961 & 146 & 97 & 65928 & 1,6 & 0,5 & 6 & 17 & 109569 & 182333 & 257988 & 27,6 & 12013 & 1209 & 17 \\
\hline B & 124609 & 149 & 98 & 69774 & 1,8 & 1,0 & 6 & 17 & $"$ & $"$ & $"$ & 9,7 & 12668 & 1254 & 16 \\
\hline C & 131707 & 152 & 99 & 69962 & 1,9 & 0,6 & 6 & 17 & $"$ & $"$ & $"$ & 9,7 & 12668 & & 16 \\
\hline
\end{tabular}

B = Bohova, Bresternica, Dogoše, Hočko Pohorje, Hrastje, Kamnica, Košaki, Limbuš, Meljski Hrib, Miklavž na Dravskem Polju, Pekel, Pekre, Pivola, Počehova, 
Razvanje, Ribniško selo, Rogoza, Rošpoh, (d), Spodnje Hoče, Vincarje, Za Kalvarijo, Zgornje Hoče, Zrkovci.

$\mathrm{C}=$ Bistrica pri Limbušu, (Bohova), Bresternica, Celestrina, Čreta, Dobravce, Dogoše, Dravski Dvor, Hotinja vas, Hrenca, Jelovec, Kamnica, Košaki, Laznica, Limbuš, Malečnik, Meljski Hrib, Miklavž na Dravskem Polju, (Orehova vas), Pekel, Pekre, Pivola, Počehova, Polana, Radizel, Razvanje, Ribniško selo, Rogoza, Skoke, Slivnica pri Mariboru, Spodnje Hoče, Trčova, Vinarje, Za Kalvarijo, Zgornje Hoče, Zrkovci.

METLIKA

\begin{tabular}{|c|c|c|c|c|c|c|c|c|c|c|c|c|c|c|c|}
\hline $\mathrm{A}$ & 3309 & 250 & 108 & 1987 & 1,7 & 3,2 & 3 & 5 & 7860 & 7418 & - & 4,0 & 550 & 1300 & 5 \\
\hline $\mathrm{B}$ & 3633 & 231 & 108 & 2207 & 1,6 & 3,5 & 3 & 5 & $"$ & $"$ & - & 3,6 & 648 & 1365 & 5 \\
\hline $\mathrm{C}$ & $"$ & $"$ & $"$ & $"$ & $"$ & $"$ & $"$ & $"$ & $"$ & $"$ & - & $"$ & $"$ & & " \\
\hline
\end{tabular}

$\mathrm{B}=$ Rosalnice, $\mathrm{C}=$ Rosalnice

MURSKA SOBOTA

\begin{tabular}{|c|c|c|c|c|c|c|c|c|c|c|c|c|c|c|c|}
\hline A & 13857 & 259 & 114 & 14783 & 0,9 & 1,4 & 5 & 7 & 35592 & 62688 & 124416 & 9,5 & 2658 & $?$ & 15 \\
\hline B & $"$ & $"$ & $"$ & $"$ & $"$ & " & $"$ & $"$ & $"$ & $"$ & $"$ & $"$ & $"$ & 1366 & " \\
\hline C & 16568 & 244 & 113 & 15724 & 1,0 & 2,9 & 5 & 7 & $"$ & $"$ & $"$ & 6,4 & 2821 & & 14 \\
\hline
\end{tabular}

$\mathrm{C}=$ Černelavci, Rakičan

NOVA GORICA

\begin{tabular}{|c|c|c|c|c|c|c|c|c|c|c|c|c|c|c|c|}
\hline A & 14638 & 378 & 103 & 10503 & 1,4 & 0,7 & 5 & 13 & 26928 & 48016 & 118261 & 41,5 & 1975 & - & 17 \\
\hline B & 20753 & 328 & 106 & 12353 & 1,7 & 1,0 & 5 & 13 & $"$ & $"$ & $"$ & 8,3 & 3185 & 1952 & 17 \\
\hline C & $"$ & $"$ & $"$ & $"$ & $"$ & $"$ & $"$ & $"$ & $"$ & $"$ & $"$ & $"$ & $"$ & & $"$ \\
\hline
\end{tabular}

B = Kromberk, Pristava, Rožna Dolina, Solkan

C = Kromberk, Pristava, Rožna Dolina, Solkan

ŠEMPETER

\begin{tabular}{|c|c|c|c|c|c|c|c|c|c|c|c|c|c|c|c|}
\hline A & 3910 & 241 & 122 & 4940 & 0,8 & 2,8 & 2 & 5 & 8861 & - & - & 5,8 & 1064 & - & 5 \\
\hline B & $"$ & $"$ & $"$ & $"$ & $"$ & " & " & " & " & - & - & $"$ & $"$ & - \\
\hline C & " & " & " & " & " & " & " & " & " & - & - & $"$ & $"$ & & 5 \\
\hline
\end{tabular}

NOVO MESTO

\begin{tabular}{|c|c|c|c|c|c|c|c|c|c|c|c|c|c|c|c|}
\hline A & 22333 & 264 & 113 & 19668 & 1,1 & 2,4 & 5 & 10 & 32585 & 52063 & 96753 & 7,4 & 3801 & 1304 & 15 \\
\hline B & $"$ & $"$ & " & $"$ & $"$ & " & " & $"$ & $"$ & $"$ & $"$ & $"$ & $"$ & 1365 & 15 \\
\hline C & 23149 & 261 & 112 & 19822 & 1,2 & 2,5 & 5 & 10 & $"$ & $"$ & $"$ & 6,4 & 3801 & & 15 \\
\hline
\end{tabular}

C = Mala Cikava, Mali Slatnik, Prečna, Srebrniče

ORMOŽ

\begin{tabular}{|c|c|c|c|c|c|c|c|c|c|c|c|c|c|c|c|}
\hline A & 2298 & 179 & 110 & 2832 & 0,8 & 3,4 & 3 & 10 & 12148 & 14446 & - & 6,0 & 533 & 1304 & 7 \\
\hline B & 2451 & 177 & 109 & 2845 & 0,9 & 4,3 & 3 & 10 & $"$ & $"$ & - & 3,8 & 533 & 1331 & 6 \\
\hline C & 2541 & 177 & 109 & 2914 & 0,9 & 4,7 & 3 & 10 & $"$ & $"$ & - & 5,1 & 533 & & 6 \\
\hline
\end{tabular}

B = Dobrava, $\mathrm{C}=$ Hardek 


\section{PIRAN}

\begin{tabular}{|c|c|c|c|c|c|c|c|c|c|c|c|c|c|c|c|}
\hline A & 4788 & 133 & 96 & 1623 & 2,9 & 1,9 & 3 & 20 & 5068 & 10390 & - & 68,4 & 179 & & 7 \\
\hline$B$ & " & $"$ & " & $"$ & $"$ & $"$ & $"$ & " & $"$ & $"$ & - & " & " & 7. st & $"$ \\
\hline C & $"$ & $"$ & " & " & $"$ & " & $"$ & " & " & $"$ & - & " & " & & \\
\hline
\end{tabular}

\section{LUCIJA}

\begin{tabular}{|c|c|c|c|c|c|c|c|c|c|c|c|c|c|c|c|}
\hline A & 5426 & 659 & 133 & 970 & 5,6 & 1,2 & 2 & 15 & 5103 & $(4845)$ & - & 12,4 & 67 & - & 6 \\
\hline B & $"$ & $"$ & $"$ & $"$ & $"$ & " & " & " & " & $"$ & - & $"$ & $"$ & - \\
\hline C & " & " & " & " & " & " & " & " & " & $"$ & - & $"$ & $"$ & & 6 \\
\hline
\end{tabular}

PORTOROŽ

\begin{tabular}{|c|c|c|c|c|c|c|c|c|c|c|c|c|c|c|c|}
\hline A & 3073 & 201 & 104 & 2562 & 1,2 & 2,2 & 2 & 7 & 2832 & - & - & 10,4 & 801 & - & 5 \\
\hline B & $"$ & $"$ & " & $"$ & " & " & " & " & " & - & - & $"$ & $"$ & - & - \\
\hline C & $"$ & " & " & $"$ & " & " & " & " & " & - & - & $"$ & $"$ & & " \\
\hline
\end{tabular}

\section{POSTOJNA}

\begin{tabular}{|c|c|c|c|c|c|c|c|c|c|c|c|c|c|c|c|}
\hline A & 8238 & 201 & 107 & 5409 & 1,5 & 0,7 & 4 & 13 & 12755 & 17025 & 29541 & 2,8 & 904 & 1498 & 10 \\
\hline$B$ & " & $"$ & $"$ & $"$ & $"$ & $"$ & " & " & " & $"$ & " & " & " & 1909 & 10 \\
\hline C & " & " & $"$ & " & $"$ & " & " & " & " & " & $"$ & " & " & & 10 \\
\hline
\end{tabular}

\section{PIVKA}

\begin{tabular}{|c|c|c|c|c|c|c|c|c|c|c|c|c|c|c|c|}
\hline A & 2105 & 107 & 91 & 1373 & 1,5 & 1,4 & 2 & 5 & 6064 & - & - & 3,3 & 280 & - & 3 \\
\hline B & 2396 & 107 & 94 & 1467 & 1,6 & 2,4 & 2 & 5 & $"$ & - & - & 2,7 & 280 & - & 3 \\
\hline C & $"$ & $"$ & $"$ & $"$ & $"$ & $"$ & $"$ & $"$ & $"$ & - & - & $"$ & $"$ & & $"$ \\
\hline
\end{tabular}

$\mathrm{B}=$ Petelinje, $\mathrm{C}=$ Petelinje

\section{PTUJ}

\begin{tabular}{|c|c|r|r|r|r|r|r|r|c|c|c|c|c|c|c|}
\hline A & 11269 & 176 & 95 & 11958 & 1,9 & 2,4 & 4 & 13 & 38632 & 68020 & 83920 & 7,3 & 2259 & $?$ & 14 \\
\hline B & 19011 & 200 & 112 & 12789 & 1,5 & 3,0 & 4 & 13 & $"$ & $"$ & $"$ & 7,0 & 2352 & 861 & 15 \\
\hline C & 20314 & 195 & 114 & 13032 & 1,6 & 3,7 & 4 & 13 & $"$ & $"$ & $"$ & 6,7 & 2352 & & 15 \\
\hline
\end{tabular}

B = Budina, Krčevina pri Ptuju, Nova vas pri Ptuju, Rabeljčja vas, Rogoznica, Spodnja Hajdina, Štuki, Vičava

$\mathrm{C}=$ Brstje, Budina, Krčevina pri Ptuju, Nova vas pri Ptuju, Orešje, Rabeljčja vas, Rogoznica, Spodnja Hajdina, Štuki, Vičava, Zgornja Hajdina, Žabjak

RADLJE

\begin{tabular}{|c|c|c|c|c|c|c|c|c|c|c|c|c|c|c|c|}
\hline A & 2644 & 199 & 112 & 1742 & 1,5 & 2,7 & 3 & 9 & 5051 & 15552 & - & 19,8 & 292 & 1268 & 7 \\
\hline B & 2890 & 180 & 111 & 1782 & 1,5 & 3,8 & 3 & 9 & $"$ & $n$ & - & 9,0 & 292 & - & - \\
\hline C & 2644 & 199 & 112 & 1742 & 1,5 & 2,7 & 3 & 9 & $"$ & $"$ & - & 19,8 & 292 & & 7 \\
\hline
\end{tabular}

B = Zgornja Vižinga 
MUTA

\begin{tabular}{|c|c|c|c|c|c|c|c|c|c|c|c|c|c|c|c|}
\hline A & 2419 & 200 & 114 & 1350 & 1,8 & 1,6 & 2 & 4 & 6197 & - & - & 4,6 & 249 & 1301 & 3 \\
\hline B & " & " & " & " & " & " & " & " & " & - & - & $"$ & & - & " \\
\hline C & " & " & " & " & " & " & " & " & " & - & - & " & & & " \\
\hline
\end{tabular}

RADOVLJICA

\begin{tabular}{|c|c|c|c|c|c|c|c|c|c|c|c|c|c|c|c|}
\hline A & 6117 & 269 & 112 & 2267 & 2,7 & 0,4 & 3 & 16 & 13316 & 24555 & - & 12,4 & 353 & 1343 & 9 \\
\hline$B$ & 9065 & 258 & 113 & 4152 & 2,2 & 0,6 & 3 & 16 & $"$ & $"$ & - & 9,1 & 718 & 1510 & 9 \\
\hline C & $"$ & $"$ & " & $"$ & " & " & $"$ & $"$ & $"$ & " & - & " & $"$ & & 9 \\
\hline
\end{tabular}

$\mathrm{B}=$ Lesce, $\mathrm{C}=$ Lesce

BLED

\begin{tabular}{|c|c|c|c|c|c|c|c|c|c|c|c|c|c|c|c|}
\hline A & 5664 & 147 & 106 & 3129 & 1,8 & 1,8 & 2 & 7 & 10486 & - & - & 4,2 & 630 & - & 7 \\
\hline B & $"$ & $"$ & " & $"$ & $"$ & " & " & $"$ & " & - & - & $"$ & 4 & 1952 & " \\
\hline C & 5849 & 147 & 107 & 3144 & 1,9 & 1,9 & 2 & 7 & $"$ & - & - & 3,7 & 630 & - & 7 \\
\hline
\end{tabular}

$\mathrm{C}=$ Koritno

RAVNE NA KOROŠKEM

\begin{tabular}{|c|c|c|c|c|c|c|c|c|c|c|c|c|c|c|c|}
\hline A & 8863 & 227 & 110 & 6705 & 1,3 & 0,1 & 3 & 3 & 10215 & 28266 & - & 43,2 & 1034 & 1361 & 11 \\
\hline B & $"$ & $"$ & $"$ & $"$ & $"$ & $"$ & " & " & $"$ & $"$ & - & $"$ & $"$ & 1952 & $"$ \\
\hline C C & 9681 & 248 & 109 & 6818 & 1,4 & 0,2 & 3 & 3 & $"$ & $"$ & - & 26,2 & 1039 & & 11 \\
\hline
\end{tabular}

$\mathrm{C}=$ Dobja vas, Dobrije

MEŽICA

\begin{tabular}{|c|c|c|c|c|c|c|c|c|c|c|c|c|c|c|c|}
\hline $\mathrm{A}$ & 3747 & 270 & 102 & 901 & 4,1 & 0,4 & 2 & 6 & 4208 & - & - & 21,5 & 160 & - & 5 \\
\hline $\mathrm{B}$ & $"$ & " & " & " & " & " & " & " & " & - & - & $"$ & $"$ & - \\
\hline $\mathrm{C}$ & " & " & " & " & " & " & " & " & " & - & - & $"$ & $"$ & - & " \\
\hline
\end{tabular}

PREVALJE

\begin{tabular}{|c|c|c|c|c|c|c|c|c|c|c|c|c|c|c|c|}
\hline $\mathrm{A}$ & 4352 & 179 & 101 & 2312 & 1,9 & 0,5 & 2 & 9 & 7357 & - & - & 14,6 & 532 & - & 6 \\
\hline $\mathrm{B}$ & " & " & " & " & " & " & " & " & $"$ & - & - & $"$ & $"$ & - & " \\
\hline $\mathrm{C}$ & " & " & " & " & " & " & " & " & " & - & - & $"$ & $"$ & - & " \\
\hline
\end{tabular}

RIBNICA

\begin{tabular}{|c|c|c|c|c|c|c|c|c|c|c|c|c|c|c|c|}
\hline A & 3302 & 244 & 99 & 3081 & 1,1 & 0,8 & 3 & 5 & 7741 & 11361 & - & 2,5 & 840 & $?$ & 6 \\
\hline B & $"$ & $"$ & $"$ & $"$ & $"$ & $"$ & " & " & $"$ & $"$ & - & $"$ & $"$ & - \\
\hline C & 3912 & 197 & 109 & 3172 & 1,2 & 1,4 & 3 & 5 & $"$ & $"$ & - & 2,5 & 840 & & 6 \\
\hline
\end{tabular}

$\mathrm{C}=$ Breg pri Ribnica, Goriča vas

RUŠE

\begin{tabular}{|c|c|c|c|c|c|c|c|c|c|c|c|c|c|c|c|}
\hline A & 4705 & 190 & 105 & 2926 & 1,6 & 1,0 & 3 & 6 & 6861 & 10586 & - & 10,5 & 755 & 1453 & 6 \\
\hline$B$ & " & " & " & " & " & $"$ & " & $"$ & $"$ & $n$ & - & " & " & - & $"$ \\
\hline C & " & $"$ & $"$ & $"$ & " & $"$ & $"$ & $"$ & " & " V & - & " & " & diste & $"$ \\
\hline
\end{tabular}


SEVNICA

\begin{tabular}{|c|c|c|c|c|c|c|c|c|c|c|c|c|c|c|c|}
\hline A & 5040 & 227 & 121 & 3805 & 1,3 & 1,3 & 3 & 3 & 13888 & 16513 & - & 10,1 & 636 & 1322 & 8 \\
\hline B & $"$ & $"$ & $"$ & $"$ & " & $"$ & " & $"$ & $"$ & $"$ & - & $"$ & " & 1952 & 8 \\
\hline $\mathrm{C}$ & $"$ & " & " & $"$ & " & $"$ & " & " & $"$ & $"$ & - & $"$ & $"$ & " & " \\
\hline
\end{tabular}

SEŽANA

\begin{tabular}{|c|c|c|c|c|c|c|c|c|c|c|c|c|c|c|c|}
\hline $\mathrm{A}$ & 4866 & 300 & 101 & 4288 & 1,1 & 0,2 & 3 & 15 & 7717 & 19053 & - & 3,1 & 1037 & - & 8 \\
\hline $\mathrm{B}$ & $"$ & " & " & " & " & " & " & " & " & " & - & " & " & 1952 & " \\
\hline C & " & " & " & " & " & " & " & " & " & " & - & " & " & & " \\
\hline
\end{tabular}

SLOVENJ GRADEC

\begin{tabular}{|r|r|r|r|r|r|r|r|r|r|r|r|r|r|r|r|}
\hline A & 6714 & 265 & 118 & 5945 & 1,1 & 0,5 & 4 & 6 & 14687 & 18546 & 57199 & 26,3 & 699 & 1251 & 12 \\
\hline B & 8316 & 265 & 117 & 6208 & 1,3 & 1,5 & 4 & 6 & $"$ & $"$ & $"$ & 8,6 & 1046 & 1267 & 12 \\
\hline C & 9671 & 239 & 115 & 6363 & 1,5 & 2,1 & 4 & 6 & $"$ & $"$ & $"$ & 6,0 & $\ldots$ & & 11 \\
\hline
\end{tabular}

$\mathrm{B}=$ Stari trg, C = Stari trg, Šmartno v Mislinjski dolini

SLOVENSKA BISTRICA

\begin{tabular}{|c|c|c|c|c|c|c|c|c|c|c|c|c|c|c|c|}
\hline A & 6683 & 260 & 110 & 5327 & 1,2 & 1,1 & 3 & 8 & 16712 & 24945 & - & 9,0 & 1129 & $13.5 t$ & 10 \\
\hline B & $"$ & $"$ & $"$ & $"$ & $"$ & $"$ & & $"$ & $"$ & $"$ & - & $"$ & $"$ & 1313 & 10 \\
\hline C & 8434 & 181 & 111 & 5533 & 1,5 & 2,1 & 3 & 8 & $"$ & $"$ & - & 4,6 & 1129 & & 9 \\
\hline
\end{tabular}

$\mathrm{C}=$ Devina, Kovača vas, Visole, Zgornja Bistrica

\section{SLOVENSKE KONJICE}

\begin{tabular}{|c|l|l|l|l|l|l|l|l|l|l|l|l|l|l|l|}
\hline $\mathrm{A}$ & 4882 & 277 & 116 & 4157 & 1,1 & 1,3 & 3 & 9 & 9940 & 15822 & - & 17,8 & 680 & 1251 & 8 \\
\hline B & 4983 & 256 & 103 & 4170 & 1,2 & 1,4 & 3 & 9 & $n$ & $"$ & - & 15,9 & 680 & 1952 & 8 \\
\hline C & 5075 & 238 & 109 & 4185 & 1,2 & 1,7 & 3 & 9 & $n$ & $"$ & - & 12,9 & 680 & & 8 \\
\hline
\end{tabular}

$\mathrm{B}=$ Blato; $\mathrm{C}=$ Blato, Škalce, Vešenik

ZREČE

\begin{tabular}{|c|c|c|c|c|c|c|c|c|c|c|c|c|c|c|c|}
\hline A & 2952 & 345 & 124 & 2772 & 1,1 & 4,4 & 2 & 2 & 5369 & - & - & 4,9 & 630 & - & 3 \\
\hline$B$ & $"$ & " & $"$ & " & " & $"$ & $"$ & " & " & - & $\overline{-}$ & " & " & - & " \\
\hline C & " & " & " & " & " & $"$ & " & " & $"$ & - & - & $"$ & " & - & $"$ \\
\hline
\end{tabular}

ŠKOFJA LOKA

\begin{tabular}{|c|c|c|c|c|c|c|c|c|c|c|c|c|c|c|c|}
\hline A & 12340 & 291 & 251 & 6562 & 1,9 & 0,4 & 3 & 7 & 16297 & 30353 & - & 7,9 & 1387 & 1248 & 12 \\
\hline B & 15448 & 213 & 137 & 8180 & 1,9 & 1,1 & 3 & 7 & $"$ & $"$ & - & 7,9 & 1656 & 1274 & 13 \\
\hline C & 16210 & 209 & 120 & 7196 & 2,2 & 1,2 & 3 & 7 & $"$ & $"$ & - & 7,7 & 1656 & & 12 \\
\hline
\end{tabular}

B = Grenc, Podpulferca, Puštal, Stara Loka, Trata, Vincarje, Virmaše

C = Binkelj, Godešič, Grenc, Hosta, Podpulferca, Puštal, Stara Loka, Suha, Sveti

Duh, (Trata), Vincarje, Virlog, Virmaše 


\section{ŽELEZNIKI}

\begin{tabular}{|c|c|c|c|c|c|c|c|c|c|c|c|c|c|c|c|}
\hline A & 3129 & 203 & 112 & 2551 & 1,2 & 1,5 & 2 & 2 & 6523 & - & - & 12,6 & 569 & 14. st & 5 \\
\hline$B$ & " & " & " & " & " & " & " & " & " & - & - & $"$ & " & - & " \\
\hline C & " & " & " & $"$ & $"$ & $"$ & $"$ & $"$ & $"$ & - & - & " & $"$ & & " \\
\hline
\end{tabular}

\section{ŽIRI}

\begin{tabular}{|c|c|c|c|c|c|c|c|c|c|c|c|c|c|c|c|}
\hline $\mathrm{A}$ & 3437 & 167 & 105 & 4153 & 1,7 & 2,0 & 2 & 2 & 4693 & - & - & 4,4 & 300 & - & 3 \\
\hline $\mathrm{B}$ & $"$ & $"$ & $"$ & $"$ & $"$ & $"$ & $"$ & $"$ & $"$ & - & - & $"$ & $"$ & - & - \\
\hline $\mathrm{C}$ & $"$ & $"$ & $"$ & $"$ & $"$ & $"$ & " & $"$ & $"$ & - & - & $"$ & $"$ & & $"$ \\
\hline
\end{tabular}

(Šmarje pri Jelšah) ROGAŠKA SLATINA

\begin{tabular}{|c|c|c|c|c|c|c|c|c|c|c|c|c|c|c|c|}
\hline A & 4904 & 345 & 114 & 4153 & 1,2 & 2,5 & 2 & 7 & 10549 & - & - & 9,4 & 538 & - & 6 \\
\hline B & $"$ & " & " & " & " & " & " & " & " & - & - & " & " & - & - \\
\hline C & 5789 & 205 & 113 & 4296 & 1,3 & 3,9 & 2 & 7 & $"$ & - & - & 5,5 & $"$ & & 6 \\
\hline
\end{tabular}

TOLMIN

\begin{tabular}{|c|c|c|c|c|c|c|c|c|c|c|c|c|c|c|c|}
\hline A & 3851 & 235 & 108 & 2274 & 1,7 & 0,4 & 3 & 10 & 7478 & 21822 & - & 14,0 & 196 & 1820 & 8 \\
\hline B & 4035 & 223 & 108 & 2291 & 1,8 & 0,9 & 3 & 10 & $"$ & $"$ & - & 8,5 & 196 & 1952 & 7 \\
\hline C & 3851 & 235 & 108 & 2274 & 1,7 & 0,4 & 3 & 10 & $"$ & $"$ & - & 14,0 & 196 & & 8 \\
\hline
\end{tabular}

$\mathrm{B}=$ Žabče

TRBOVLJE

\begin{tabular}{|c|c|c|c|c|c|c|c|c|c|c|c|c|c|c|c|}
\hline A & 17485 & 120 & 102 & 8952 & 1,9 & 0,1 & 4 & 8 & 21542 & 21542 & 47838 & 13,8 & 1685 & 1926 & 13 \\
\hline B & $"$ & $"$ & $"$ & $"$ & $"$ & " & $"$ & $"$ & $"$ & $"$ & $"$ & $"$ & $"$ & 1952 & 12 \\
\hline C & 17994 & 119 & 102 & 9201 & 1,9 & 0,1 & 4 & 8 & $"$ & $"$ & $"$ & 11,1 & 1685 & & 12 \\
\hline
\end{tabular}

$\mathrm{C}=$ Gabrsko, Ojstro

\section{TREBNJE}

\begin{tabular}{|c|c|c|c|c|c|c|c|c|c|c|c|c|c|c|c|}
\hline A & 2804 & 259 & 120 & 2006 & 1,4 & 1,9 & 3 & 8 & 9709 & 14988 & - & 7,2 & 262 & - & 7 \\
\hline B & $"$ & $"$ & $"$ & $"$ & $"$ & $"$ & " & $"$ & $"$ & $"$ & - & $"$ & $"$ & - \\
\hline C & 3086 & 233 & 120 & 2057 & 1,5 & 3,1 & 3 & 8 & $"$ & $"$ & - & $"$ & $"$ & & 6 \\
\hline
\end{tabular}

$\mathrm{C}=$ Dolenja Nemška vas, Pekel

TRŽIČ

\begin{tabular}{|c|c|c|c|c|c|c|c|c|c|c|c|c|c|c|c|}
\hline A & 4206 & 102 & 106 & 3529 & 1,2 & 0,2 & 3 & 6 & 14544 & 14544 & - & 7,9 & 554 & 1492 & 8 \\
\hline$B$ & 8250 & 157 & 103 & 4770 & 1,7 & 0,3 & 3 & 6 & " & " & - & 8,5 & 692 & 1926 & 8 \\
\hline C & 9445 & 164 & 101 & 5009 & 1,9 & 0,4 & 3 & 6 & " & " & - & 1,6 & 692 & & 7 \\
\hline
\end{tabular}

$\mathrm{B}=$ Bistrica pri Tržiču, Ročevnica, Slap, C = Bistrica pri Tržiču, Loka, Pristava, Ročevnica, Slap 
VELENJE

\begin{tabular}{|c|c|c|c|c|c|c|c|c|c|c|c|c|c|c|c|}
\hline A & 27337 & 472 & 120 & 18778 & 1,5 & 0,2 & 4 & 2 & 28076 & 37671 & 38818 & 21,7 & 3975 & 1374 & 15 \\
\hline B & $"$ & $"$ & $"$ & $"$ & $"$ & $"$ & " & " & $"$ & $"$ & $"$ & $"$ & $"$ & 1952 & " \\
\hline C & 29545 & 488 & 119 & 18932 & 1,6 & 0,6 & 4 & 2 & $"$ & $"$ & $"$ & 8,9 & 3975 & & 14 \\
\hline
\end{tabular}

$\mathrm{C}=$ Bevče, Hrastovec, Paka pri Velenju, Podkraj pri Velenju, Škale

ŠOŠTANJ

\begin{tabular}{|c|c|c|c|c|c|c|c|c|c|c|c|c|c|c|c|}
\hline A & 2950 & 119 & 93 & 1906 & 1,5 & 0,9 & 2 & 7 & 8801 & - & - & 8,0 & 562 & \multirow{3}{*}{$\begin{array}{l}1348 \\
1911\end{array}$} & 5 \\
\hline B & $"$ & " & " & " & " & $"$ & " & " & " & - & - & $"$ & " & & $"$ \\
\hline C & 3717 & 103 & 87 & 2016 & 1,8 & 1,6 & 2 & 7 & $"$ & - & & 2,6 & 562 & & 4 \\
\hline
\end{tabular}

$\mathrm{C}=$ Družmirje, Lokovica

VRHNIKA

\begin{tabular}{|c|c|c|c|c|c|c|c|c|c|c|c|c|c|c|c|}
\hline A & 7019 & 209 & 110 & 3860 & 1,8 & 1,2 & 3 & 7 & 14081 & 15812 & - & 3,7 & 700 & 1325 & 8 \\
\hline B & 8685 & 205 & 110 & 4260 & 2,0 & 1,3 & 3 & 7 & $n$ & $"$ & - & 3,2 & 796 & 1952 & 7 \\
\hline C & 9085 & 200 & 110 & 4330 & 2,1 & 1,6 & 3 & 7 & $"$ & $"$ & - & 3,1 & 796 & & 7 \\
\hline
\end{tabular}

$\mathrm{B}=$ Verd

$\mathrm{C}=$ Sinja Gorica, Verd

ZAGORJE

\begin{tabular}{|c|c|c|c|c|c|c|c|c|c|c|c|c|c|c|c|}
\hline A & 7428 & 179 & 103 & 3294 & 2,2 & 0,3 & 3 & 5 & 13738 & 16494 & - & 27,0 & 445 & - & 8 \\
\hline B & " & $"$ & $"$ & " & $"$ & $"$ & $"$ & $"$ & $"$ & $"$ & - & " & " & 1952 & " \\
\hline $\bar{C}$ & 10309 & 141 & 102 & 3800 & 2,7 & 0,3 & 3 & 5 & " & " & - & 10,9 & 445 & & 7 \\
\hline
\end{tabular}

$\mathrm{C}=$ Dolenja vas, Kisovec, (Loke), (Podkraj pri Zagorju), Selo pri Zagorju

ŽALEC

\begin{tabular}{|c|c|c|c|c|c|c|c|c|c|c|c|c|c|c|c|}
\hline A & 5314 & 274 & 121 & 3532 & 1,5 & 1,9 & 3 & 12 & 15712 & 30845 & - & 17,9 & 638 & 1258 & 12 \\
\hline B & $"$ & $"$ & $"$ & $"$ & $"$ & " & " & $"$ & $"$ & $"$ & - & $"$ & $"$ & 1966 & 12 \\
\hline C & 7642 & 141 & 102 & 3800 & 2,7 & 3,7 & 3 & 12 & $"$ & $"$ & - & 4,7 & 638 & & 9 \\
\hline
\end{tabular}

$\mathrm{C}=$ Gotovlje, Ložnica pri Žalcu, Vrbje 
Tabela 10: Pregled uvrstitve mest in mestnih naselij glede na dosežene točke po variantah $\mathrm{A}, \mathrm{B}, \mathrm{C}$

\begin{tabular}{|c|c|c|c|}
\hline $\begin{array}{c}\text { Toč } \\
\text { ke }\end{array}$ & Varianta A & Varianta B & Varianta C \\
\hline 18 & Celje, Koper, Ljubljana & Celje, Koper, Ljubljana & Ljubljana \\
\hline 17 & Kranj, Maribor, Nova G. & Nova Gorica & Celje, Koper, Nova Gorica \\
\hline 16 & & Kranj, Maribor, & Kranj, Maribor \\
\hline 15 & $\begin{array}{l}\text { Murska Sobota, Novo } \\
\text { mesto, Velenje (Ravne-- } \\
\text { Prevalje) }\end{array}$ & $\begin{array}{l}\text { Murska Sobota, Novo mesto, } \\
\text { Ptuj, Velenje (Ravne- } \\
\text { Prevalje) }\end{array}$ & $\begin{array}{l}\text { Novo mesto, Ptuj, (Ravne- } \\
\text { Prevalje) }\end{array}$ \\
\hline 14 & Jesenice, Ptuj & Domžale & Domžale, Murska S. Velenje \\
\hline 13 & Trbovlje & Škofja Loka, & \\
\hline 12 & $\begin{array}{l}\text { Domžale, Krško, Slovenj } \\
\text { Gradec, Škofja Loka, } \\
\text { Žalec }\end{array}$ & $\begin{array}{l}\text { Jesenice, Kamnik, Krško, } \\
\text { Slovenj Gradec, Trbovlje, } \\
\text { Žalec }\end{array}$ & $\begin{array}{l}\text { Jesenice, Kamnik, Krško, } \\
\text { Škofja Loka, Trbovlje }\end{array}$ \\
\hline 11 & $\begin{array}{l}\text { Brežice, Kamnik, Ravne, } \\
\text { (Piran-Portorož-Lucija) }\end{array}$ & $\begin{array}{l}\text { Brežice, Ravne, (Piran- } \\
\text { Portorož-Lucija) }\end{array}$ & $\begin{array}{l}\text { Brežice, Ravne, Slovenj } \\
\text { Gradec, (Piran-Portorož- } \\
\text { Lucija) }\end{array}$ \\
\hline 10 & \begin{tabular}{|l|} 
Ajdovščina, Izola, \\
Kočevje, Postojna, \\
Slovenska Bistrica \\
\end{tabular} & $\begin{array}{l}\text { Ajdovščina, Postojna, } \\
\text { Slovenska Bistrica }\end{array}$ & $\begin{array}{l}\text { Ajdovščina, Kočevje, } \\
\text { Postojna }\end{array}$ \\
\hline 9 & $\begin{array}{l}\text { Črnomelj, Grosuplje, } \\
\text { Radovljica }\end{array}$ & $\begin{array}{l}\text { Grosuplje, Izola, Kočevje, } \\
\text { Radovljica }\end{array}$ & $\begin{array}{l}\text { Črnomelj, Grosuplje, Izola, } \\
\text { Radovljica, Slovenska Bistr. }\end{array}$ \\
\hline 8 & $\begin{array}{l}\text { Litija, Sevnica, Sežana, } \\
\text { Slovenske Konjice, } \\
\text { Tolmin, Tržič, Vrhnika, } \\
\text { Zagorje } \\
\end{array}$ & $\begin{array}{l}\text { Črnomelj, Litija, Sevnica, } \\
\text { Sežana, Slovenske Konjice, } \\
\text { Tržič, Zagorje }\end{array}$ & $\begin{array}{l}\text { Litija, Sevnica, Sežana, } \\
\text { Slovenske Konjice, Tolmin, } \\
\text { Žalec }\end{array}$ \\
\hline 7 & $\begin{array}{l}\text { Bled, Dravograd, Hras- } \\
\text { tnik, Idrija, Laško, Len- } \\
\text { dava, Medvode, Ormož, } \\
\text { Piran, Radlje, Trebnje } \\
\end{array}$ & \begin{tabular}{|l|} 
Bled, Dravograd, Hrastnik, \\
Idrija, Laško, Medvode, \\
Piran, Tolmin, Trebnje, \\
Vrhnika \\
\end{tabular} & $\begin{array}{l}\text { Bled, Dravograd, Hrastnik, } \\
\text { Idrija, Medvode, Piran, } \\
\text { Radlje, Tržič, Vrhnika, } \\
\text { Zagorje }\end{array}$ \\
\hline 6 & $\begin{array}{l}\text { Gornja Radgona, Ilirska } \\
\text { Bistrica, Lucija, } \\
\text { Ljutomer, Prevalje, } \\
\text { Ribnica, Rogaška Slatina, } \\
\text { Ruše } \\
\end{array}$ & $\begin{array}{l}\text { Gornja Radgona, Ilirska } \\
\text { Bistrica, Lucija, Ljutomer, } \\
\text { Ormož, Prevalje, Radlje, } \\
\text { Ribnica, Rogaška Slatina }\end{array}$ & $\begin{array}{l}\text { Gornja Radgona, Ilirska } \\
\text { Bistrica, Laško, Lendava, } \\
\text { Lucija, Ljutomer, Ormož, } \\
\text { Prevalje, Ribnica, Rogaška } \\
\text { Slatina, Ruše, Trebnje, }\end{array}$ \\
\hline 11 & $\begin{array}{l}\text { Cerknica, Lenart, Loga- } \\
\text { tec, Mengeš, Metlika, } \\
\text { Mežica, Portorož, } \\
\text { Radenci, Šempeter/G., } \\
\text { Šoštanj, Železniki } \\
\end{array}$ & $\begin{array}{l}\text { Cerknica, Lenart, Lendava, } \\
\text { Logatec, Mengeš, Metlika, } \\
\text { Mežica, Portorož, Radenci, } \\
\text { Šempeter/G., Šoštanj, } \\
\text { Železniki } \\
\end{array}$ & $\begin{array}{l}\text { Cerknica, Lenart, Logatec, } \\
\text { Mengeš, Metlika, Mežica, } \\
\text { Portorož, Radeče, Radenci, } \\
\text { Šempeter/G., Železniki }\end{array}$ \\
\hline 4 & & ( & Šoštanj \\
\hline 3 & $\begin{array}{l}\text { Muta, Radeče, Pivka, } \\
\text { Zreče, Žiri }\end{array}$ & $\begin{array}{l}\text { Muta, Pivka, Radeče, Zreče, } \\
\text { Žiri }\end{array}$ & Muta, Pivka, Zreče, Žiri \\
\hline 2 & Senovo & Senovo & Senovo \\
\hline
\end{tabular}


Dobljeni razpored mestnih naselij na podlagi točkovanja različnih kazalcev urbanosti, mestnega pomena in vloge dopušča, da oblikujemo naslednje sklepe

1. Uporabljene tri variante (A, B, C) niso bistveno spreminjale razporeditve mest. V glavnem je dodajanje obmestnih naselij k mestnemu jedru zniževalo število točk, ker se je znižala gostota prebivalstva, ali se je zmanjšal indeks rasti, ali se je spremenilo razmerje med bivajočimi in zaposlenimi, ali pa se je povečal delež kmečkega prebivalstva. Sodimo, da bi bilo vendarle pravilneje, da bi pri končnem sklepanju upoštevali varianti $\mathrm{B}$ in $\mathrm{C}$, in ne varianto $\mathrm{A}$, pri kateri so $\mathrm{v}$ določenih primerih obmestna urbana naselja že priključili $\mathrm{k}$ nekaterim mestom, $\mathrm{v}$ drugih pa ne. Menimo tudi, da je variamta $\mathrm{C}$ bolj objektivna od variante $\mathrm{B}$, saj pri slednji niso uporabili enotnih meril in niso upoštevali vseh obmestnih urbanih naselij. Če sodimo, da so pri varianti $\mathrm{C}$ morda vprašljivi kriteriji, jih je mogoče spremeniti ali dopolniti. Dobljeni rezultati po tej varianti so strokovno še najbolj smiselni.

2. Sodimo, da večina naselij, ki je dosegla šest ali več točk, izkazuje mestni značaj. Vprašljiva je le uvrstitev nekaterih industrijskih naselij (Medvode, Ruše), turističnih krajev (Bled, Rogaška Slatina), manjših središč (Radlje, Ribnica, Trebnje) ali satelitskih naselij (Lucija, Prevalje) $v$ to skupino. Po drugi strani so $v$ razred $s$ petimi točkami prišla $v$ glavnem naselja, ki doslej niso imela mestnega statusa (z izjemo Metlike po $C$ varianti), oziroma so se izraziteje urbanizirala šele v zadnjih desetletjih (Lenart, Cerknica, Logatec, Šempeter/G., Mežica). Glede na to je razmejitev med razredoma s šestimi oziroma petimi točkami kar prepričljiva. Vzrok za slabo uvrstitev nekaterih mest $s$ pretežmo urbanim značajem ozirom urbano tradicijo (Gornja Radgona, Ilirska Bistrica, Ljutomer; Lendava, Ormož) je treba iskati v njihovem šibkem zaledju, populacijski stagnaciji, večjem deležu kmečkega prebivalstva ali nizki gostoti prebivalstva.

3. Položaj nekaterih mest bi se bistveno spremenil, če bi jih združili v somestja. Navajamo dva takšna primera za somestji Ravne-Prevalje in Piran-Portorož-Lucija. Združitev je toliko prepričljivejša, ker si navedena naselja že sedaj medsebojno delijo opravila in funkcije. Verjetno bi bilo smiselno združiti naselja še v nekaterih primerih (npr. Velenje-Šoštanj).

SOMESTJE PIRAN-PORTOROŽ-LUCIJA

\begin{tabular}{|c|c|c|c|c|c|c|c|c|c|c|c|c|c|c|c|}
\hline $\mathrm{A}$ & 13287 & 192 & 110 & 5155 & 2,6 & 1,9 & 3 & 20 & 13003 & 10390 & - & 16,9 & 1978 & & 11 \\
\hline $\mathrm{B}$ & $"$ & $"$ & $"$ & $"$ & $"$ & $"$ & " & $"$ & $"$ & $"$ & - & $"$ & $"$ & & 11 \\
\hline $\mathrm{C}$ & $"$ & " & " & " & " & " & " & " & $"$ & $"$ & - & $"$ & $"$ & & 11 \\
\hline
\end{tabular}

SOMESTJE RAVNE-PREVALJE-DOBJA VAS

\begin{tabular}{|c|c|c|c|c|c|c|c|c|c|c|c|c|c|c|c|}
\hline A & 13939 & 222 & 106 & 9123 & 1,5 & 0,3 & 3 & $?$ & 17572 & 28266 & - & 22,7 & 1751 & & 15 \\
\hline B & $"$ & " & $"$ & $"$ & " & " & " & " & " & " & - & $"$ & $"$ & & " \\
\hline C & " & " & " & " & " & " & " & " & $"$ & " & - & " & " & & " \\
\hline
\end{tabular}


4. Iz prikazane razporeditve vseh slovenskih mest glede na njihov pomen in urbanost je končno mogoče tudi sklepati, katera mesta bi nedvomno zaslužila naslov mestne občine. To bi bila po naši sodbi lahko vsa tista mestna naselja, ki so presegla 11 točk; mednje bi se uvrstila: Brežice, Celje, Domžale, Jesenice, Kamnik, Koper, Kranj, Krško, Ljubljana, Maribor, Murska Sobota, Nova Gorica, Novo mesto, PiranPortorož-Lucija, Ptuj, Ravne (ali Ravne-Prevalje), Slovenj Gradec, Škofja Loka, Trbovlje in Velenje. S tem bi tudi popravili prvotno razvrstitev mestnih občin, ki je rezultat zakonske opredelitve, da se med mestne občine lahko uvrste le mesta $\mathrm{z}$ več kot 10.000 prebivalci.

Glede na javno razpravo je Državni zbor sprejel med drugim dve preformulaciji zakonskega besedila, ki zadevata tudi obravnavano problematiko. Besedilo o mestnih občinah se sedaj glasi: "Mestna občina je gosto in strnjeno naselje ali več naselij, povezanih $\mathrm{v}$ enoten prostorski organizem in mestno okolico, ki jo povezuje dnevna migracija prebivalstva." Isti člen je tudi spremenil kriterije za opredelitev mestne občine: "Mesto lahko dobi status mestne občine, če ima najmanj 20.000 prebivalcev in najmanj 15.000 delovnih mest, od tega najmanj polovico $\mathrm{v}$ terciarnih in kvartarnih dejavnostih in je geografsko, gospodarsko in kulturno središče svojega gravitacijskega območja." Uvedel je tudi pojem mesta: "Mesto je večje urbano naselje, ki se po velikosti, ekonomski strukturi, prebivalstveni gostoti, naseljenosti in zgodovinskem razvoju razlikuje od drugih naselij. Ima več kot 3000 prebivalcev. Status mesta dobi z odločitvijo Državnega zbora. Glede mest, ki so status mesta dobila že v skladu s predpisi, veljavnimi v času podelitve, Državni zbor samo ugotovi, da že imajo status mesta."

\section{BIBLIOGRAFIJA}

Abecedni spisak mešovitih i gradskih naselja. Savezni zavod za statistiku, Beograd, 1961.

Cerovac, P. 1966: Porast števila prebivalstva mest v SR Sloveniji od leta 1869 do 1966, Prikazi in študije, XII/11-12. Ljubljana.

Cerovac, P. 1974: O problematiki prikazovanja mest in mestnih naselij v SR Sloveniji (1945-1973), Prikazi in študije, XX/št. 5-6. Ljubljana.

Imenik naselij v SR Sloveniji, Stanje 1.7. 1982, Ljubljana, 1982.

Popis prebivalstva, gospodinjstev in stanovanj v SR Sloveniji za I. 1991; Zavod za statistiko R Slovenije, Ljubljana, 1991.

Popis prebivalstva, gospodinjstev in stanovanj v SR Sloveniji 31.3 1981, Ljubljana, 1984.

Popis stanovništva 1953, Stanovništvo i domačinstva, knjiga XIII, Beograd, 1959.

Pregled naselij po občinah Republike Slovenije in pregled občin SFRJ, Stanje 
31.12.1990, Zavod Republike Slovenije za statistiko, Metodološko gradivo, št. 3/91, Ljubljana, 1991.

Rebec, J. 1983: Razvoj naselij mestnega značaja z več kot 2000 prebivalci v SR Sloveniji 1971-1981, Prikazi in študije, XXVIII/ Ljubljana.

Seznam sprememb naselij SR Slovenije (Preimenovanja, pristavki, združitve, razdružitve in razglasitve) od leta 1948 do 1984, Zavod SR Slovenije za statistiko, Ljubljana, julij, 1985.

Spisak gradskih naselja s šiframa opština i naselja - prema popisu stanovnika i stanova 1971. godine, Beograd, 1971.

Statistični letopis (S)R Slovenije, 1964-1993, Pregled po mestnih naseljih. Ljubljana. Uradni list LRS 8/49, Uradni list LRS 11/52, Uradni list LRS 19/52, Uradni list LRS 24/53, Uradni list LRS 24/55, Uradni list SRS 35/64.

Vrišer, I. 1974: Mesta in urbano omrežje v SR Sloveniji. Značilnosti njihovega razvoja in družbeno gospodarskega pomena s posebnim ozirom na mala mesta, Geografski zbornik, XIV/3, SAZU. Ljubljana.

Vrišer, I. 1988: Centralna naselja v SR Sloveniji leta 1987, Geografski zbornik, XXVIII/3, SAZU. Ljubljana.

Vrišer, I. 1990: Ekonomskogeografska regionalizacija Republike Slovenije, Geografski zbornik, XXX. Ljubljana.

Vrišer, I.; Rebernik, D. 1993: Družbenogospodarska in dejavnostna usmeritev slovenskih mest, Geografski zbornik, XXXIII. Ljubljana.

\section{DEFINITION OF CITIES AND CITY MUNICIPALITIES IN SLOVENIA}

\section{Summary}

By passing the Local Autonomy Act (UL RS 72/93 of Dec 31, 1993) the Parliament of the Republic of Slovenia set the foundations for new municipalities and, also introduced the category of "city municipality" into the Slovenian administrative system. The latter should be formed in "the areas of bigger cities. As a rule, they should have over 10,000 residents each, and should be geographical, economic and cultural centers of their gravitation areas. Only exceptionally, the status of a city municipality could be allocated to a city for historical reasons."

Because of the obscurity of the above definition, the state administration asked for an expert study on how many cities in Slovenia could be ranked into this category which also entails greater autonomy. Two expert studies were elaborated: one by Marjan 
Ravbar, Ph.D., and the current one. It has turned out that the problems are more complex, and that it would also be necessary to re-introduce the category of city which was abandoned in the sixties after the indroduction of "communes" (big municipalities). As to these facts, the study first attempts to evaluate which settlements with more than 10,000 residents could be ranked into the category of city municipalities; the second part presents the valorization of the urban importance of individual cities in Slovenia, made on the basis of 13 indicators. In both cases, the assessment was expressed in points. The evaluation of the potential city municipalities has been based on the following indicators:

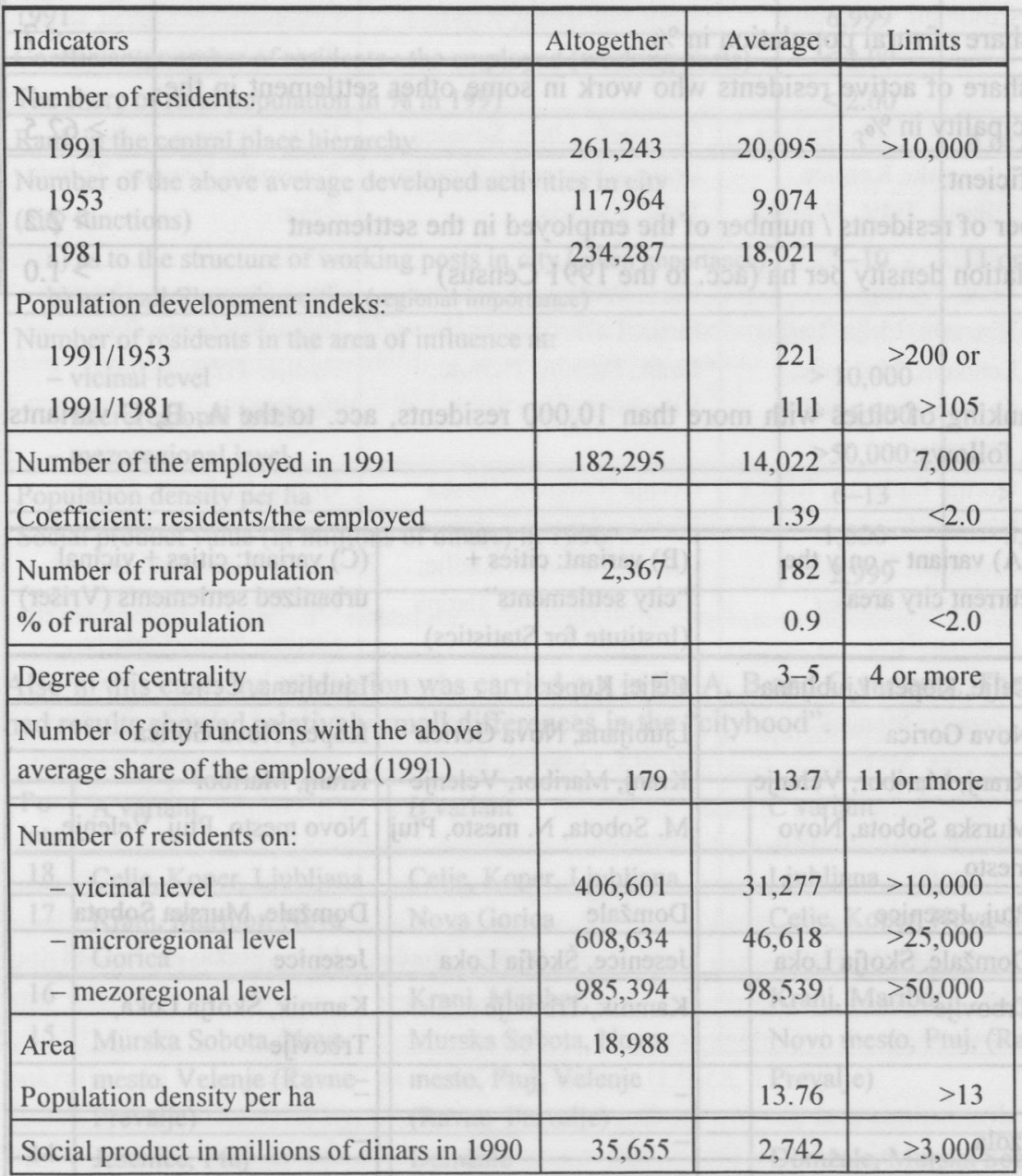


Establishing the degree of "cityhood" has shown considerable differences between individual cities, due to the incorporation of neighbouring settlements into the cities. Therefore, the evaluation was carried out in three variants; we took into account: (A) the pure city only; (B) the city and the vicinal settlements which had already been taken as city parts by the Statistic Service, and (C) according to the author's criteria, the vicinal urbanized settlements were added to the city. The criteria employed were as follows:

\begin{tabular}{|l|r|}
\hline $\begin{array}{l}\text { Population development: index 1991/1953 } \\
\text { index 1991/1981 }\end{array}$ & $\begin{array}{r}>130 \\
\text { or }>104\end{array}$ \\
\hline The share of rural population in \% & $<7$ \\
\hline $\begin{array}{l}\text { The share of active residents who work in some other settlement in the } \\
\text { municipality in \% }\end{array}$ & $>62.5$ \\
\hline $\begin{array}{l}\text { Coefficient: } \\
\text { number of residents / number of the employed in the settlement }\end{array}$ & $>2.2$ \\
\hline Population density per ha (acc. to the 1991 Census) & $>1.0$ \\
\hline
\end{tabular}

The ranking of cities with more than 10,000 residents, acc. to the A, B, C variants, was as follows:

\begin{tabular}{|r|l|l|l|}
\hline $\begin{array}{r}\text { Poi } \\
\text { nts }\end{array}$ & $\begin{array}{l}\text { (A) variant - only the } \\
\text { current city area }\end{array}$ & $\begin{array}{l}\text { (B) variant: cities + } \\
\text { "city settlements" } \\
\text { (Institute for Statistics) }\end{array}$ & $\begin{array}{l}\text { (C) variant: cities + vicinal } \\
\text { urbanized settlements (Vrišer) }\end{array}$ \\
\hline 11 & Celje, Koper, Ljubljana & Celje, Koper & Ljubljana, Celje \\
\hline 10 & Nova Gorica & Ljubljana, Nova Gorica & Koper, Nova Gorica \\
\hline 9 & Kranj, Maribor, Velenje & Kranj, Maribor, Velenje & Kranj, Maribor \\
\hline 8 & $\begin{array}{l}\text { Murska Sobota, Novo } \\
\text { mesto }\end{array}$ & M. Sobota, N. mesto, Ptuj & Novo mesto, Ptuj, Velenje \\
\hline 7 & Ptuj, Jesenice & Domžale & Domžale, Murska Sobota \\
\hline 6 & Domžale, Škofja Loka & Jesenice, Škofja Loka & Jesenice \\
\hline 5 & Trbovlje & Kamnik, Trbovlje & $\begin{array}{l}\text { Kamnik, Škofja Loka, } \\
\text { Trbovlje }\end{array}$ \\
\hline 4 & & - & - \\
\hline 3 & Izola & - & - \\
\hline 2 & & Izola & Izola, Kočevje, Zagorje \\
\hline
\end{tabular}


The assessment of the "cityhood" of settlements with more than 2,000 residents was carried out by applying similar criteria and points.

\begin{tabular}{|c|c|c|c|}
\hline Criteria & & 1 point & 2 points \\
\hline \multicolumn{2}{|c|}{$\begin{array}{l}\text { Number of residents in } 1991 \text {; settlements of }>2,000 \text { residents } \\
\text { were taken into account. }\end{array}$} & $\begin{array}{c}5,000 \\
9,999 \\
\end{array}$ & $>10,000$ \\
\hline \multicolumn{2}{|c|}{$\begin{array}{r}\text { Population development: index 1991/1953 } \\
\text { index 1991/1981 }\end{array}$} & $\begin{array}{l}>200 \text { or } \\
>105\end{array}$ & \\
\hline \multirow{2}{*}{\multicolumn{2}{|c|}{$\begin{array}{l}\text { Number of the employed (working posts) in the settlement in } \\
1991\end{array}$}} & $1,500-$ & $>7,000$ \\
\hline & & 6,999 & $00010+8$ \\
\hline \multicolumn{2}{|c|}{ Coefficient; number of residents : the employed (working posts) } & $<2.00$ & 169 \\
\hline \multicolumn{2}{|c|}{ The share of rural population in \% in 1991} & $<2.00$ & \\
\hline \multicolumn{2}{|c|}{ Rank in the central place hierarchy } & 3 & 4 or more \\
\hline \multicolumn{2}{|c|}{$\begin{array}{l}\text { Number of the above average developed activities in city } \\
\text { (city functions) } \\
\text { a) as to the structure of working posts in city (urban importance) } \\
\text { b) as to all Slovenian cities (regional importance) }\end{array}$} & $5-10$ & 11 or more \\
\hline $\begin{array}{l}\text { Number of residents in the ar } \\
\text { - vicinal level } \\
\text { - microregional level } \\
\text { - mezoregional level }\end{array}$ & influence at: & $\begin{array}{l}>10,000 \\
>25,000 \\
>50,000\end{array}$ & 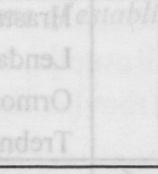 \\
\hline Population density per ha & 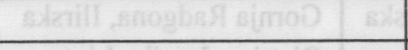 & $6-13$ & \multirow{2}{*}{$>3,000$} \\
\hline \multicolumn{2}{|c|}{ Social product value (in millions of dinars) in 1990} & $\begin{array}{l}1,000- \\
2,999\end{array}$ & \\
\hline
\end{tabular}

Also in this case, the evaluation was carried out in the A, B and C variants. The obtained results showed relatively small differences in the "cityhood".

\begin{tabular}{|c|l|l|l|}
\hline $\begin{array}{l}\text { Po- } \\
\text { ints }\end{array}$ & A variant & B variant & C variant \\
\hline 18 & Celje, Koper, Ljubljana & Celje, Koper, Ljubljana & Ljubljana \\
\hline 17 & $\begin{array}{l}\text { Kranj, Maribor, Nova } \\
\text { Gorica }\end{array}$ & Nova Gorica & Celje, Koper, Nova Gorica \\
\hline 16 & & Kranj, Maribor, & Kranj, Maribor \\
\hline 15 & $\begin{array}{l}\text { Murska Sobota, Novo } \\
\text { mesto, Velenje (Ravne- } \\
\text { Prevalje) }\end{array}$ & $\begin{array}{l}\text { Murska Sobota, Novo } \\
\text { mesto, Ptuj, Velenje } \\
\text { (Ravne-Prevalje) }\end{array}$ & $\begin{array}{l}\text { Novo mesto, Ptuj, (Ravne- } \\
\text { Prevalje) }\end{array}$ \\
\hline 14 & $\begin{array}{l}\text { Jesenice, Ptuj } \\
\text { Domžale }\end{array}$ & $\begin{array}{l}\text { Domžale, Murska Sobota, } \\
\text { Velenje }\end{array}$ \\
\hline
\end{tabular}




\begin{tabular}{|c|c|c|c|}
\hline 13 & Trbovlje & Škofja Loka, & \\
\hline 12 & $\begin{array}{l}\text { Domžale, Krško, } \\
\text { Slovenj Gradec, Škofja } \\
\text { Loka, Žalec }\end{array}$ & $\begin{array}{l}\text { Jesenice, Kamnik, Krško, } \\
\text { Slovenj Gradec, Trbovlje, } \\
\text { Žalec }\end{array}$ & $\begin{array}{l}\text { Jesenice, Kamnik, Krško, } \\
\text { Škofja Loka, Trbovlje }\end{array}$ \\
\hline 11 & $\begin{array}{l}\text { Brežice, Kamnik, Ravne, } \\
\text { (Piran-Portorož-Lucija) }\end{array}$ & $\begin{array}{l}\text { Brežice, Ravne, (Piran- } \\
\text { Portorož-Lucija) }\end{array}$ & $\begin{array}{l}\text { Brežice, Ravne, Slovenj } \\
\text { Gradec, (Piran-Portorož- } \\
\text { Lucija) }\end{array}$ \\
\hline 10 & Ajdovščina, Izola, & Ajdovščina, Postojna, & Ajdovščina, Kočevje, \\
\hline & Kočevje, Postojna, & Slovenska Bistrica & Postojna \\
\hline & Slovenska Bistrica & & 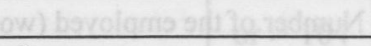 \\
\hline 9 & $\begin{array}{l}\text { Črnomelj, Grosuplje, } \\
\text { Radovljica }\end{array}$ & $\begin{array}{l}\text { Grosuplje, Izola, Kočevje, } \\
\text { Radovljica }\end{array}$ & $\begin{array}{l}\text { Črnomelj, Grosuplje, Izola, } \\
\text { Radovljica, Slovenska }\end{array}$ \\
\hline & & 250 & Bistrica \\
\hline 8 & $\begin{array}{l}\text { Litija, Sevnica, Sežana, } \\
\text { Slovenske Konjice, } \\
\text { Tolmin, Tržič, Vrhnika, } \\
\text { Zagorje }\end{array}$ & $\begin{array}{l}\text { Črnomelj, Litija, Sevnica, } \\
\text { Sežana, Slovenske Konjice, } \\
\text { Tržič, Zagorje }\end{array}$ & $\begin{array}{l}\text { Litija, Sevnica, Sežana, } \\
\text { Slovenske Konjice, Tolmin, } \\
\text { Žalec }\end{array}$ \\
\hline 7 & $\begin{array}{l}\text { Bled, Dravograd, } \\
\text { Hrastnik, Idrija, Laško, } \\
\text { Lendava, Medvode, } \\
\text { Ormož, Piran, Radlje, } \\
\text { Trebnje }\end{array}$ & $\begin{array}{l}\text { Bled, Dravograd, Hrastnik, } \\
\text { Idrija, Laško, Medvode, } \\
\text { Piran, Tolmin, Trebnje, } \\
\text { Vrhnika }\end{array}$ & $\begin{array}{l}\text { Bled, Dravograd, Hrastnik, } \\
\text { Idrija, Medvode, Piran, } \\
\text { Radlje, Tržič, Vrhnika, } \\
\text { Zagorje }\end{array}$ \\
\hline $60 i$ & $\begin{array}{l}\text { Gornja Radgona, Ilirska } \\
\text { Bistrica, Lucija, } \\
\text { Ljutomer, Prevalje, } \\
\text { Ribnica, Rogaška } \\
\text { Slatina, Ruše } \\
\end{array}$ & $\begin{array}{l}\text { Gornja Radgona, Ilirska } \\
\text { Bistrica, Lucija, Ljutomer, } \\
\text { Ormož, Prevalje, Radlje, } \\
\text { Ribnica, Rogaška Slatina }\end{array}$ & $\begin{array}{l}\text { Gornja Radgona, Ilirska } \\
\text { Bistrica, Laško, Lendava, } \\
\text { Lucija, Ljutomer, Ormož, } \\
\text { Prevalje, Ribnica, Rogaška } \\
\text { Slatina, Ruše, Trebnje, }\end{array}$ \\
\hline 5 & $\begin{array}{l}\text { Cerknica, Lenart, } \\
\text { Logatec, Mengeš, } \\
\text { Metlika, Mežica, } \\
\text { Portorož, Radenci, } \\
\text { Šempeter/G., Šoštanj, } \\
\text { Železniki }\end{array}$ & $\begin{array}{l}\text { Cerknica, Lenart, Lendava, } \\
\text { Logatec, Mengeš, Metlika, } \\
\text { Mežica, Portorož, Radenci, } \\
\text { Šempeter/G., Šoštanj, } \\
\text { Železniki }\end{array}$ & $\begin{array}{l}\text { Cerknica, Lenart, Logatec, } \\
\text { Mengeš, Metlika, Mežica, } \\
\text { Portorož, Radeče, Radenci, } \\
\text { Šempeter/G., Železniki }\end{array}$ \\
\hline 4 & 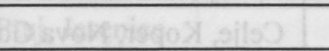 & 20000 & Šoštanj \\
\hline 3 & $\begin{array}{l}\text { Muta, Radeče, Pivka, } \\
\text { Zreče, Žiri }\end{array}$ & $\begin{array}{l}\text { Muta, Pivka, Radeče, Zreče, } \\
\text { Žiri }\end{array}$ & Muta, Pivka, Zreče, Žiri \\
\hline 2 & Senovo & Senovo & Senovo \\
\hline
\end{tabular}

Public discussions and the two studies resulted in the change of criteria for the definition of city municipalities ( $>20,000$ residents), and in the re-introduction of the category "city" into the Local Autonomy Act. 